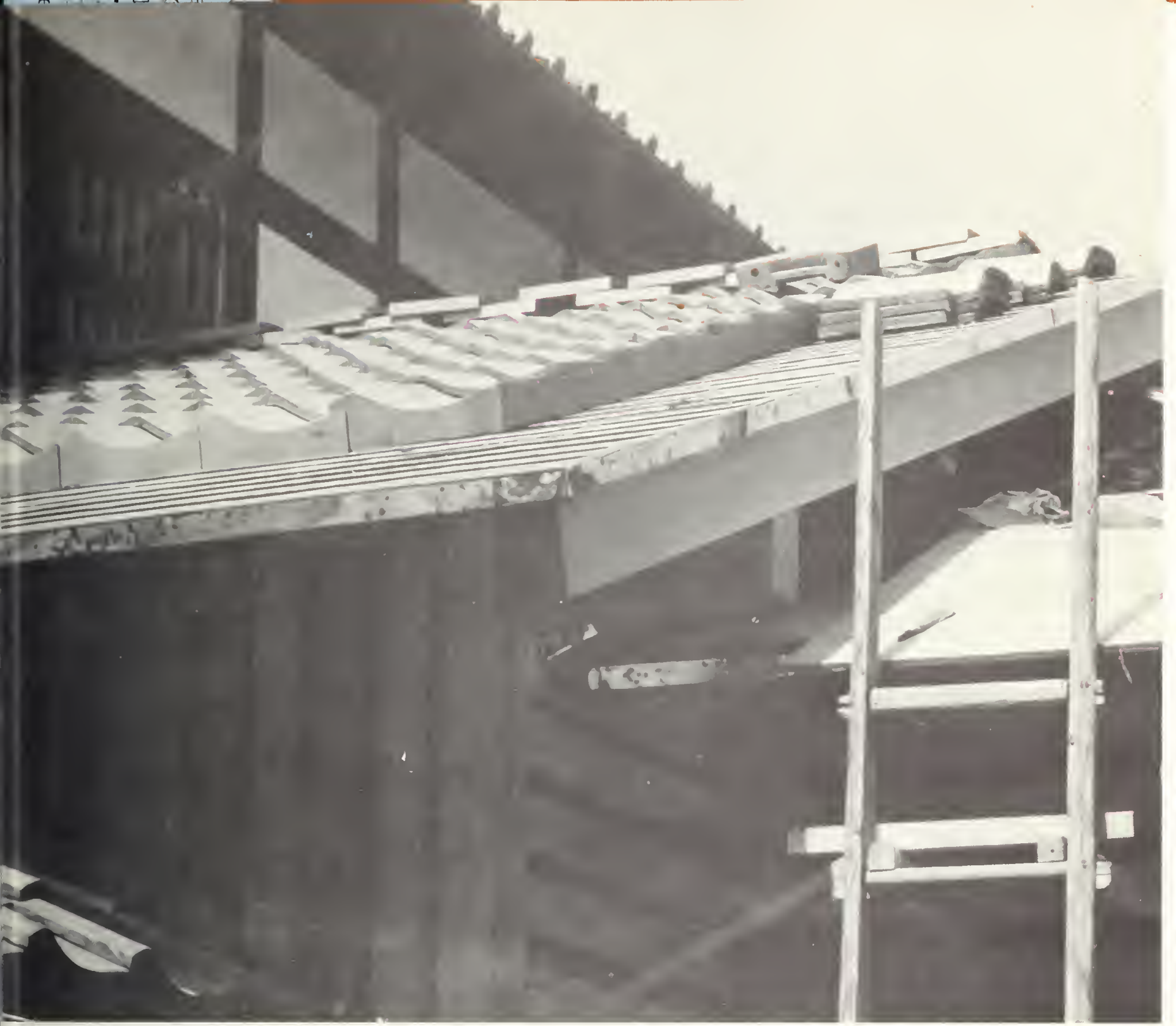

NBSIR 77-1411

\title{
INTERNATIONAL RESEARCH
}

The FY 1977 Suroey of CBT's International Programs

Center for Building Technology Institute for Applied Technology Washington, D.C. 20234
U.S. Department of Commerce National Bureau of Standards March 1978 



\section{INTERNATIONAL RESEARCH \\ The FY1977 Survey of CBT's International Programs}

Center for Building Technology Institute for Applied Technology National Bureau of Standards

Washington, D.C. 20234

March 1978

U.S. DEPARTMENT OF COMMERCE, Juanita M. Kreps, Secretary

Dr. Sidney Harman, Under Secretary

Jordan J. Baruch, Assistant Secretary for Science and Technology

NATIONAL BUREAU OF STANDARDS, Ernest Ambler, Director 

This report presents the international research activities of the Center for Building Technology during the transition quarter and Fiscal Year 1977. In general, the objectives of this work were to spread the results of building research worldwide in hopes of creating a better built environment. Last year CBT continued working closely with less-developed countries to improve their building practices. The Center also continued cooperative research efforts with a number of countries that have acknowledged expertise in particular areas of building research, such as England, Israel, and France, to name but a few. On such projects, the Center pursued common research goals alongside the building researchers from other nations on studies of critical importance to all nations, such as energy and natural resources conservation.

Key words: Building practices; building research; codes and standards; housing; international cooperation; technology transfer. 

Introduction. . . . . . . . . . . . . . . . . . . . . . . . . 1

Bangladesh. . . . . . . . . . . . . . . . . . . . . . . 2

Bulgaria. . . . . . . . . . . . . . . . . . . . . . . . . 4

Brazil. . . . . . . . . . . . . . . . . . . . . . . . . 7

Canada. . . . . . . . . . . . . . . . . . . . . . . . 8

CENTO: Iran, Pakistan, Turkey. . . . . . . . . . . . . . . . . . 12

Egypt . . . . . . . . . . . . . . . . . . . . . . . . . . 13

England . . . . . . . . . . . . . . . . . . . . . . . . 15

Finland . . . . . . . . . . . . . . . . . . . . . . . . 18

France. . . . . . . . . . . . . . . . . . . . . . . . 20

India . . . . . . . . . . . . . . . . . . . . . . . . 25

Indonesia . . . . . . . . . . . . . . . . . . . . . . . . 27

Israe 1. . . . . . . . . . . . . . . . . . . . . . . . 29

Italy . . . . . . . . . . . . . . . . . . . . . 32

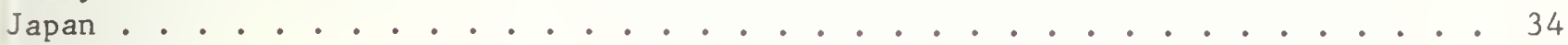

Philippines . . . . . . . . . . . . . . . . . . . . 36

Poland. . . . . . . . . . . . . . . . . . . . . . 37

Romania . . . . . . . . . . . . . . . . . . . . . . 39

Spain . . . . . . . . . . . . . . . . . . . . . . . 4 40

Sweden. . . . . . . . . . . . . . . . . . . . . . . 42

U.S.S.R. •. . . . . . . . . . . . . . . . . . . . . 4 47

International Organization Memberships. . . . . . . . . . . . . . . . 52

СЕВ. . . . . . . . . . . . . . . . . . . . . 53

CIB. . . . . . . . . . . . . . . . . . . . 55

$\operatorname{DESBRO}$. . . . . . . . . . . . . . . . . . 56

ISO. . . . . . . . . . . . . . . . . . . . 57

International Energy Agency. . . . . . . . . . . . . . . 59

International Seminar on Heat Transfer in Buildings. . . . . . . . . 61

International Total Energy Congress: ITEC . . . . . . . . . . . . 62

North At lantic Treaty Organization: CCMS-MIUS Project . . . . . . . 64

RILEM. . . . . . . . . . . . . . . . . . . . 67

List of Foreign Guest Workers . . . . . . . . . . . . . . . . . . 70

Research Organizations. . . . . . . . . . . . . . . . . . . . 71

List of Foreign Visitors. . . . . . . . . . . . . . . . . . . 74 



\section{INTRODUCTION}

International research activities at the Center for Building Technology (CBT) are of two kinds: either individual agreements with other nations to jointly pursue common building research goals, or institutional memberships with multinational research organizations. In both kinds of arrangement, however, the object of CBT's work is the same: to spread the results of building research to the building community worldwide. Beyond that, the aim is for improved building practices in the U.S. building community and throughout the world.

In contrast to this, CBT's arrangements to cooperate in large ventures with building research groups in other industrialized nations is a prudent attempt to avoid costly and time-consuming duplication of effort. It is also an admission that no one country has an edge over the others in building research. Some nations have acknowledged expertise in certain areas such as: England, for total energy systems; Sweden, for rehabilitation; Israel, for water conserving plumbing systems; and Russia, for the analysis of blended cements. CBT, in turn, has a similar catalog of expertise that is attractive to building decisionmakers in other countries. For these reasons, it is expected that international arrangements like those in this report will continue to expand over the years. Likewise, tours of foreign building sites and analysis of international technology will continue to be a source of ideas for domestic building techniques. 


\section{BANGLADESH}

The results of $\mathrm{CBT}^{\prime} \mathrm{s}$ project, sponsored by the Agency for International Development, to improve the performance of low-rise buildings in nations prone to high winds are watched with great interest in Bangladesh. Jamiliu Choudhury, Professor, Civil Engineering, of the University of Engineering and Technology, Dacca, is responsible for transferring the project's results to other countries and groups within the Bay of Bengal area, and to groups including the World Bank and the United Nations Development Program. Other follow-on activities that will be led by Jamiliu Choudhury will be a series of workshops, each on one of the project's four technical areas: wind loads and design criteria; building practices for masonry connectors and timber fasteners; forecasting housing needs; and socio-economic and architectural considerations. The material on wind loads and masonry connectors/ timber fasteners will be used as engineering text material starting with the 1977 fall semester at the Dacca University. (See the Philippine section of this report for a more complete description of the high-wind study.)

The University was also the site of a talk on the CBT high-wind project, given by Noel J. Raufaste, Assistant to the Director of CBT for Program Planning. The meeting was attended by approximately 60 government and private engineers, including such individuals as the chief architect of the government, several deputy directors, and private consulting engineers.

At the CARE, Inc. facility in Dacca, Noel Raufaste viewed the low-cost plastichouse manufacturing operation. In four years, the production facility has expanded from 7 to 35 employees. A number of plastic buildings are being produced: single-family homes, school buildings, warehouses, and grain silos. Most of these orders are from government and relief agencies, e.g., AID, UNESCO, UNDP 3 World Bank, etc. The original concept of producing a house for $\$ 21$ US per $m^{2}$ has not been possible. Costs are averaging about $\$ 64$ US per $\mathrm{m}^{2}$. At this cost, the homes are more expensive than brick houses. The plastic houses do make good service buildings, however, especially those that will be moved several times during their life. The buildings are easy to construct and dismantle because they bolt together. 
CARE donated a quonset house in 1974 to the Philippines for use by CBT as a test house in their high-wind research study. It was instrumented with pressure transducers. Wind loads were recorded during storm passages and wind tunnel tests were performed on the building. Detailed technical results on the performance of the house, in field and wind-tunnel conditions, were given to the CARE facility in Dacca during Spring 1977. 


\section{BULGARIA}

A series of week-long seminars were held in both Bulgaria and Poland during March 1977, with the expressed purpose of applying U.S. experience and materials to the industrialized building needs of these Eastern European nations. Both seminars were chaired by Porter Driscol1, Manager of CBT's Design and Construction Technology Application Program.

In Bulgaria, the Ministry of Construction is responsible for carrying out state policy regarding the built environment. Decisions regarding urban and regional growth are made at a political level drawing upon information furnished by this organization through their research and development activities. Once the decision to build " $X$ " number of units in a given location has been reached, the physical form is established by designers within the Ministry.

There are five basic functions of the design elements of the Ministry: (1) Research and Development. This activity covers a broad spectrum including sociological, economic, and physical technology research on the form of urban buildings and neighborhoods, building materials, and the development and introduction of new techniques of construction.

(2) The Development of Standards and Standardization. This activity builds on the Ministry research and development activities as well as on information gained through participation in international standards organizations. (3) Organization and Management of Design Activities. Since all physical planning and design is done by this large organization, there is great emphasis on Architectural and Engineering productivity. (4) "Typezation." The development of standard building components, subsystems and units. To achieve economies of scale and to promote the industrialization of construction activities, great emphasis has been placed upon "standard plans" for individual apartment units. Even though no larger scale of standardization was intended there is a certain element of monotony in some of the apartment buildings made up of these standard units. (5) Innovative Techniques and Inventions (including licensing). Under this program, innovative techniques and new materials are accepted for incorporation into building practice in Bulgaria. 
These functions all take place to achieve national housing goals which have been identified by political means. The national goal is one dwelling unit per family and one room within that dwelling unit for each person in the family. A married couple is counted as one person. The goal is to develop housing that is flexible enough to permit change in function over time, and housing that makes effective use of space and equipment to promote the health of the occupants. It is also recognized that housing establishes the character of large portions of the city; therefore, close attention is paid to the esthetics of buildings and groups of buildings.

The need for new buildings is described in terms of five-year plans. The sociological goal for 1980 is to reduce the number of families sharing dwellings to $5 \%$ of the total families in the country. The goal in 1985 is $4 \%$; in 1990 , is $1.8 \%$. It has been established that the last figure represents the number of families who are voluntarily sharing dwellings units. This includes, of course, extended families of two or more generations. The production of these dwelling units will be $73 \%$ in urban areas and $27 \%$ in rural. Thus, 1990 will see the end of an intensive Bulgarian effort to provide sheer numbers of dwelling units; after 1990, emphasis will be placed upon raising the quality of residential units and neighborhoods through supplying amenities that cannot now be afforded.

Fifty percent of all new construction is of large panel concrete, and Bulgaria's industrialized building factories produce from 1,000 to 5,000 dwelling units per year, depending upon market size and location. The present labor input is 16 to 18 manhours per square meter of completed building and the goal is 10 to 12 manhours per square meter. Productivity is a major concern of the Bulgarian building community. Much use is made of modules, precast elevator hoistways, and precast foundations. Large panel construction is also used in shops and hotels as well as in housing units.

An additional $22 \%$ of construction is created by means of the lift-slab method using a Bulgarian modification featuring short stub steel columns that are raised successively with each floor's final placement afier shoring on in-situ cast concrete columns.

An unusual building using the lift-slab method is a 22-story building in downtown Sophia that had a slip-form central core containing stairs, elevators, and all utilities. The top of this building has an expanded core unit consisting of cast-in-place concrete cantilevers extending 30 feet out from each side of the square core unit to provide a support hanger for the outboard edges of all slabs. A jacking system that has 32 lift points is used, and the control console is at the top of the building. All floor slabs are cast in the usual lift-slab manner and each slab, before it is hoisted into place, has placed upon it all the finishing materials required. It is hoisted slightly ( 1.5 meters) to permit the exterior cladding to be affixed and then the whole is lifted complete with all bulky materials needed for the completion of that floor. 
The third form of construction, which accounts for a large part of the balance of Bulgarian industrialized construction technique, is the use of large forms or tunnel forms. The Bulgarians are also doing considerable work on light aggregate concrete and are only now beginning to utilize sandwich construction for exterior nonbearing walls. 


\section{BRAZIL}

CBT is taking part in a joint program between the U.S. and Brazil to improve the staff capabilities of the Instituto de Pesquisas Tecnologicas (IPT), Sao Paulo, in the general area of building technology, with emphasis on the development and measurement techniques needed for performance standards. This program is part of the NBS/IPT Collaborative Program under the US-Brazil Joint Group on Science and Technology Memorandum of Understanding.

During the past year, the first IPT staff member completed his 2-year rotating assignment at CBT, during which he participated on research in all divisions of the Center. Two new Brazilian staffers began working on separate projects in the Building Services Section of the Center. A third Brazilian staff member is working in CBT's Materials and Composites Section.

In addition, Thomas K. Faison, Assistant Chief of CBT's Office of Housing and Building Technology, and project coordinator, traveled to Brazil to review the state of the Brazilian construction industry with an eye to how the special problems of Brazil mesh with the Center's research programs.

But this cooperation between Brazil and the United States is not just a one-way street. A new project is concerned with an exchange between CBT and IPT on natural weathering at various environmental exposure sites. IPT is in the process of establishing three sites in Brazil. IPT is also interested in learning more about the measurement techniques used by CBT for correlation determinations (accelerated versus natural weathering conditions).

Further, one of the conditions established by CBT management in carrying out the IPT/CBT program is that programs are not initiated for the sole purpose of IPT training. The major benefit to CBT is the gaining of professional assistance at a time when CBT is severely limited by a personnel ceiling. In addition to the staff trainees who will be working in the laboratory in support of an ongoing activity, the programs fund a portion of the project leader's time for orientation, training, and supervision. An intangible benefit will be the exposure of our staff to the trainees to gain some insight into problems unique to the Brazilian building design/construction/regulation process. 


\section{CANADA}

The Center is collaborating with the Division of Building Research (DBR) of Canada's National Research Council in a study of crowd movement during the XXI Olympiad in Montreal, July 1976. Using videotape and film, the DBR/CBT team recorded the flows of large groups of spectators as they moved into, out of, and around the olympic Stadium and other facilities constructed for the Games. These records are now being analyzed to identify the performance of various architectural systems with respect to rates of egress from the different arenas, the flow of crowds to and from adjacent transport facilities, and pedestrian movement on aisles, stairs, and escalators.

Late in 1976, John Archea, a research psychologist from CBT's Architectural Research Section, visited DBR to review some 87 hours of videotype and super-eight film, and to begin coordinating the research results.

DBR will provide CBT with a detailed index of the entire tape and film library soon, and a joint DBR/CBT report that describes the scope, procedure, and preliminary findings of the study in general terms will be compiled.

In addition to meeting with representatives of DBR, Alan Gilmour and Tad Ogrodnik of the Department of National Health and Welfare in Canada were visited. Mr. Gilmour is particularly interested in CBT's use of the Consumer Product Safety Commission's National Electronic Injury Surveillance system in conjunction with the stair safety research conducted in 1973-75. A similar system is contemplated to document non-highway accidents in Canada. Mr. Ogrodnik is primarily interested in describing a study that his office is conducting on stair use for interfloor movement in high-rise office buildings. His study involves both the conservation of energy (due to lower utilization of elevators for interfloor movement of less than three floors) and the physical fitness aspects of stair climbing as a form of exercise. He is particularly concerned with the tradeoffs between the energy conservation or physical fitness issues and the problems of stair safety that had been investigated at CBT. 
Likewise, John S. Stroik, a research architect with CBT's Architectural Research Section, who is also vice-chairman of ASTM Committee F-12 on Security Systems, met with Byron Johnson, of DBR, who is preparing a symposium on better building security to resist burglary and vandalism. Also present at the meeting was H.U.V. James of the Royal Canadian Mounted Police, who will also be participating in the symposium. Emphasis of the symposium will be building form/layout and its relationship to criminal behavior and crime. The Canadian symposium although in the planning stage also, has received comments of interest from the Canadian Standards Association, the Canadian National Building Code, local police departments, Royal Canadian Mounted Police, the Planning and Architecture Department of Edmonton University.

In cases such as these two, DBR and CBT work has been linked through active participation in the same standards and professional society committees. However, improved cooperation, with management attention, could promote more efficient research and technical services by reducing duplication of work and applying the resources conserved to topics which otherwise could not be treated. Complementary programs permit attainment of these objectives without loss of independence, tortuous management processes, or complicated exchanges of funding. In complementary projects, each institution arranges objectives, milestones, and schedules so that activities are mutually supportive.

The following appear to be good target areas for complementary projects. In each, CBT proposes to continue negotiations by having section chiefs and project leaders meet to develop complementary activities.

Metrication is pending for the Canadian building industry. Therefore, there is great interest in cooperative work in technical support for the transition in the areas of dimensional coordination. That is, what modules should be used for the building dimensions that govern the sizes of building products, what tolerances are appropriate, the catalog of the sizes to be provided (e.g., appropriate dimensions for standard sheets of wallboard and the number of discrete thicknesses to be stocked). These concerns are a major activity in ISO TC-59, Building Construction.

Canadian studies of wind forces on buildings have emphasized tall buildings, while ours have emphasized low buildings. There has been general coordination of activities, visits, common committee participation, and regular correspondence. Attention will be given to field and wind tunnel research, design procedures, and standards development.

DBR has an ongoing project on progressive collapse, as has CBT. Complementary activities may include laboratory studies of the phenomenon and philosophical approaches to its treatment in design standards.

Materials research at DBR has included studies of the mechanisms of degradation in nature and characterizations of environmental exposure. In a complementary project, the environments at the CBT exposure sites can be characterized on the same bases and coordinated programs of testing may use the sites of the two organizations. 
DBR is beginning studies of the mechanisms of degradation of bituminous roofing materials and $\mathrm{CBT}$ has a substantial ongoing prograin for development of test methods for the characterization of roofing physical properties.

Energy conservation research and technical services programs are active in both organizations. For instance, DBR has studied moisture movement in building enclosures for some 20 years and CBT sees need for expanded activities in this area because of recent increases in amounts of insulation.

Architects in both DBR and CBT are looking at the way people use buildings and seeking rational bases for major classes of criteria such as those intended to provide safe egress in emergencies. CBT has the advantage of research staff expertise in the behavioral sciences, which could be of considerable assistance to DBR in the planning of their experiments. Since the DBR has somewhat more direct access to implementation of such findings in building codes, there are mutual benefits of complementary work.

In September 1976, Hans J. Milton attended the Eighteenth Meeting of Steering Committee 5 (Construction Industry) of the Metric Commission of Canada, by invitation of the Sector Plan Manager. The principal purpose of the trip was to become acquainted with the state of metrication in the Canadian construction community and key sectors within it, such as design, production, codes and standards, and governmental activity. Specific objectives included: (1) The assessment of general metric preparedness and activity relative to the changeover date (M-date) agreed by the Canadian construction community--January 1, 1978; (2) To identify areas of special interest to the U.S. construction community and, in particular, the NBS/CBT metrication/dimensional coordination program; (3) To identify any specific problems or bottlenecks; (4) To meet with members of the Steering Committee on metrication in the Canadian construction community to develop first-hand points of contact for exchange of information and U.S./Canadian liaison on research aspects of metrication. In the end, it was agreed to develop a joint U.S.-Canadian/Standard of metric practice.

In October, 1976, Richard Marshall, Structural Research Engineer, in CBT's Structures Section attended the meeting of the AISI/MBMA/CSICC Joint Task Committee on Wind Research. The purpose of this meeting was to review the results of model studies being carried out at the Boundary Layer Wind Tunnel Laboratory, University of Western Ontario, London, Ontario. His participation was as an advisory member of the Task Committee and as a representative of ANSI Committee A58, Subcommittee on Wind Loads. This research program is concerned with the effects of wind on prefabricated industrial metal buildings and the research findings are expected to form the basis for the next revision of certain wind load provisions of American National Standard A58.1 -"Minimum Design Loads in Buildings and Other Structures". In addition to this meeting, discussions were held with research staff of the Boundary Layer Wind Tunnel Laboratory concerning results of a recent NBS study of wind loads on mobile homes and the tentative design criteria developed from this study. 
On another study, William L. Carroll, a physicist in CBT's Thermal

Engineering Section, travelled to Ottawa to confer with DBR specialists on the design and construction of guarded hot plates and hot boxes.

DBR has one of the best-equipped laboratories in the world for thermal conductance measurements of building insulation materials. This equipment has the capability to test insulations up to about $20-25 \mathrm{~cm}$ thick, in a variety of configurations and thermal conditions. In addition, DBR has two hot boxes capable of testing building wall systems. Most of the time was spent discussing merits and problems with the existing apparatus, based on DBR's operating experiences. DBR recommended building at least two new hot plates if CBT wants to have a broad measurement capability. DBR offered copies of the shop drawings for their apparatus, and informed CBT what they would do differently if they were to build such apparatus now. DBR also offered to give CBT copies of the detailed drawings for their guarded hot boxes.

Late in 1976, James G. Gross, Chief of CBT's Office of Building Standards and Codes Services, traveled to Ottawa to participate in the National Research Council (NRC) Ad Hoc Review Committee on the National Building Code of Canada. The purpose of this trip was to review NRC's activities with respect to the National Building Code. Particular attention was paid to the effectiveness of NRC's current role, and to assess whether the following are appropriate in relation to the NRC work in support of the Code:

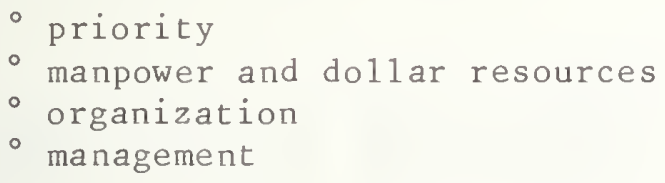

Further, he was asked to recommend the future direction of Canada'a National Building Code and its subcommittees. 


\section{CENTO: IRAN, PAKISTAN, TURKEY}

Late in 1976, Charles Culver, Manager of CBT's Disaster Mitigation Program, participated in a seminar on Recent Advances in Earthquake Hazard Minimization. The seminar was one of a series of scientific conferences held by the Central Treaty Organization (CENTO) to enable scientists from the CENTO regional countries (Iran, Pakistan, Turkey) to exchange ideas and to learn of recent progress. The meeting was held in Tehran and included participation by the CENTO countries, the United Kingdom, and the United States. A similar seminar was held in Ankara, Turkey in 1968.

Among other papers, M. Amin from Arya-Mehr University of Technology in Tehran described construction of a shaking table at the University. The Table will have one component of horizontal motion and will use a 100-kip MTS hydraulic ram.

Work at Pahlavi University in Shiraz, Iran on masonry structures was of interest in view of the CBT masonry research program. Their program involving small-wall tests and prism tests is directed toward developing a failure hypothesis for unreinforced masonry and is similar to that at CBT, although they were not aware of our efforts. Pahlavi University staff was advised of CBT's program and were sent copies of recent CBT reports on masonry. Continued exchange of research results with the group at Pahlavi University would be worthwhile as the CBT program proceeds.

Analytical studies by Dr. Amin of the response of piping systems in nuclear power plants were also of interest in connection with CBT work on developing design procedures for service systems subjected to earthquake loading. Dr. Amin's work involved simplified design procedures based on ground-motion spectra. 


\section{EGYPT}

In September 1977, James R. Wright, Acting Director of the Institute for Applied Technology, and William C. Cullen, Assistant Chief of CBT's Structures, Materials, and Safety Division, traveled to Cairo to discuss priority projects under consideration by the Joint U.S./Egyptian Working Group, new projects assigned to the Standards and Application Panel, and to obtain on-site information regarding the status of the Egyptian building construction community.

Among other subjects for future joint study was a "Study of Building Raw Materials," a proposal that has been developed by Dr. Ramez of Egypt's Building Research Institute (BRI). Dr. Hifnawi, Director of BRI, agreed and predicted a high probability of success. Further, he urged that the constraints to funding be identified and removed. It was agreed to put ihis on the agenda for the September 12, 1977, meeting when the Egyptian members of the Building Materials and Technology Study Panel, as well as representatives of the Science Office of the U.S. Embassy, including AID, would be present.

There was also a meeting with His Excellency Architect Hassan Mohamed Hassan, the Minister of Housing and Reconstruction as well as the Minister's Counsellor, Engineer Ahmed Salat.

Addison Richmond, the Science Officer of the U.S. Embassy and Jim Reilly who represented AID, were particularly helpful in suggesting ways and means of obtaining resources. They posed answers to some of the questions which arose, e.g., What direction to take? What criteria are appropriate? What organizations have resources to fund these projects? Addison Richmond suggested NBS, NSF, AID and OSTP as potential sponsors. Jim Reilly pointed out that the probability for AID funding will be significantly higher if the project could be incorporated into an existing, or future, larger project which is, or will be funded. (This suggestion proved to be very beneficial in our discussions with A. Abou E1-Azm, the President of the Academy of Scientific Research and Technology.) Addison Richmond also volunteered to accept the responsibility to forward approved proposals to various agencies for consideration as sponsors. In addressing the constraints 
to obtaining resources, he felt that the Working Group on Science and Technology has limited organizational or institutional backup, such as that enjoyed by the Health Group, to support its functions in Egypt or in the U.S. 


\section{ENGLAND}

Since 1971, cooperative programs between England and the United States have been conducted by CBT working with the Building Research Establishment (BRE), in Garston, Watford, England. Last year, this cooperation was concentrated in three areas: plumbing research, heat pumps, and wind loads on buildings.

Plumbing Research

Since 1972, CBT and BRE have worked together on the design of water supply and drainage installation in buildings. A computer program is available at BRE for sizing drainage and vent stacks on traditional as well as single-stack systems (the latter are simplified systems that are now beginning to win application in the USA). BRE has welcomed the chance to gain further field data for comparison with its computer program prediction and CBT received a copy of their computer program design use. Adaptation. for U.S. conditions required attention to 1) pressure loss factors appropriate to U.S. fittings, and 2) flow rates appropriate to U.S. fixtures.

Second, both BRE and CBT have an interest in new drainage systems that are coming on the market, especially in respect to health and safety requirements, water economy, and economics. BRE has conducted some drainage tests; and CBT, under a Department of Defense, TriServices sponsored project, developed criteria for the evaluation of vacuum drainage systems. The results of all these studies were collated and shared.

Third, in the area of water demand loads, a sound theoretical framework as well as adequate field data are required for the specification of plumbing systems design loads and storage requirements. Current methods are not rigorous and are known to lead to over-design. BRE has developed a theoretical basis for improved design load estimation. CBT has completed the installation of field measurement instruments and procedures 
for the evaluation of field data at Twin Rivers, N.J., and at Andrews Air Force Base, Maryland. Interpretive data reports are being compiled and have been provided to BRE. Even though the UK and the US have somewhat different plumbing systems, a common theoretical framework has emerged.

In October, 1976, the draft materials for a final report on these three areas of common plumbing research was prepared. This draft was developed by Cyril Webster of BRE and Lawrence S. Galowin, Chief of CBT's Building Services Section. As for the future of joint plumbing research, a new listing of BRE interests has been prepared for CBT review; CBT responded with a corresponding list of research topics.

Heat Pumps

The maximum potential from universal application of electrically driven heat pumps for space and hot water heating to existing housing has been estimated by BRE to be about $11 \%$ of the total UK consumption of primary energy for all purposes. This ranks heat pumps as one of the two most effective means of conserving energy in England. Similar savings can be expected in the United States. Under this study, CBT and BRE have agreed to exchange laboratory and field data on the dynamic performance of heat pumps, as well as exchange experimental measurement techniques. A comparison of different computer models of heat pumps will be undertaken. Testing procedures to evaluate the operating performance of heat pumps and complementary field demonstrations of the feasibility of engine-driven heat pumps for residential and/or commercial application will also be staged. A complementary program to improve the seasonal performance of heat pumps either by component improvement or by combining the heat pump with storage systems, solar collectors, and/or fossil fuel boosters is also underway.

Joseph Chi, a mechanical engineer in CBT's Mechanical Systems Section, visited BRE to present the CBT heat pump and furnace/boiler evaluation procedures. As a result, BRE would to like to use CBT's computer programs to help their study of controls for boilers. At present, two new test buildings are under construction, a heat-pump test facility and a boiler test facility. A U.S. made heat pump was installed on the heat pump test facility and two heat pumps of German and Swiss make were stand-by. Different approaches to frost problems were noticed in the designs of outdoor coils for U.S. and European heat pumps.

Joseph Chi also visited the Imperial College in London, where flame turbulence, chemical reactions, and heat transfer are studied in detail.

Wind Loads on Buildings

For more than five years, wind loads have been the subject of intense study by both nations under this agreement. Last year, work continued on this front with joint consultations in the areas of performance criteria for wind tunnels, comfort criteria for pedestrians, and loads on low-rise buildings, including wind pressure data on the CBT mobile 
home and on a full-scale variable-roof slope building in Aylesbury, England. In the area of high-rise buildings, recent full-scale experiments carried out by Peter Sparks (BRE) can be successfully used in verifying models for torsional and across-wind response to be developed by NBS. The two nations also collaborated on instrumentation, particulary pressure transducers. The detailed results of work carried out by BRE in connection with North Sea off-shore drilling platforms were made available to CBT. Little work of this kind is on hand in the U.S.

Further consultations were held between Emil Simiu, Structural Research Engineer of CBT's Structures Section and with BRE staff over their report "Wind Environment Around Buildings". There, it was concluded that the current comfort criterion whereby wind speeds at a given outdoor location should not exceed $1 \mathrm{~m} / \mathrm{s}$ more than $10 \%$ of the time should be modified if the wind rose (i.e., the dominant wind direction) at that location is taken into account. This report could serve as a useful basis for a joint BRE/CBT guide to the design of outdoor spaces for pedestrian comfort. The BRE results of a study of progressive collapse of buildings induced by gas explosions is similarly of interest. They show limited or low effectiveness of steel ties.

At Cambridge University, Emil Simiu conferred with J. C. R. Hunt, of the Department of Engineering. Topics discussed included code provisions on wind flow over hills, comfort criteria for pedestrians in open spaces, and the variation of dynamic wind loads with height above ground. 


\section{FINLAND}

Geoffrey Frohnsdorff, Chief of CBT's Materials and Composites Section, visited Finland's Technical Research Center (TRC) to review their building materials research activities. In general, the Technical Research Center draws on information from the U.S. and Europe through a data network that gives direct access to major data bases, including NTIS (the National Technical Information Service, in Washington). Much of the information stored in the Research Center is on microfiche. Although NBS reports are highly regarded by Mr. Laitinen, Director of the Information Center, he expressed disappointment that many of the older NBS reports are not indexed in NTIS or other computer data bases.

The Concrete Laboratory has a staff of about 90. It is largely a testing lab and research is at a low level. However, an attempt is now being made to re-establish a long-term concrete research program. The Fire Technology Laboratory, which was shown by Mr. Oksanen, a Research Engineer, was claimed to be the best equipped in Scandinavia and it is being expanded by the addition of a new building for large scale tests. It carries out research on fire safety properties of building materials, products, elements and buildings.

The Wood Preservation Laboratory staff indicated that one of their most serious current problems is with a fungus that, once it has become established in wood under wet conditions, will continue to grow on and destroy even dry wood. This fungus also grows on urea/formaldehyde and other foam insulations. A recent large increase in the incidence of damage caused by this fungus (Melitus domesticus) is attributed to improper practices in repair and renovation of houses. A somewhat similar fungus is known to occur in the U.S. In a discussion of wood preservatives, it was suggested that copper chromium arsenate is the most effective and that the treatment can be permanent if carried out properly. The Metals and Metallurgy Lab carries out studies on metal physics, physical metallurgy, welding technology, process metallurgy, and corrosion prevention. The laboratories are well-equipped for instrumental analysis. A major project is on corrosion at welds in nuclear reactors. 
There are two Building Laboratories, one in Otaniemi and one in Helsinki. The staff of about 50 carries out research on building materials, equipment, and components, and on building acoustics. The largest part of the materials work is on organic building materials such as plastic pipe, degradation mechanisms of plastics (a joint Nordic project), foam insulation, and flooring materials. Other work is on inorganic coatings for masonry and atmospheric corrosion of metals in buildings (another joint Nordic project). The joint Nordic projects have participation of about eight laboratories in Finland, Norway, Sweden, Denmark and Iceland, and about eight outdoor exposure sites are used.

After the Helsinki RILEM conference (discussed later in this report) William C. Cullen, Assistant Chief of CBT's Structures, Materials, and Safety Division, visited Tampere, the second largest city in Finland (population 166,000), located about 170 kilometers northwest of Helsinki. It was selected for the post Symposium excursion because it is the site of the Tampere Technical University and the "new town" of Hervanta, which is located in surburban Tampere.

The group (approximately 80) travelled to Tampere by bus and was welcomed at the City Hall where there was an illustrated talk by the Chief Town Planner of Tampere on the planning and development of the new town of Hervanta. Following the lecture there was a tour of the new town, which consisted of residential units from single family to multi-family high-rise buildings. The interesting concept is that industry and business is also attracted to the area in such a quantity that the number of jobs available is equal to the number of housing units.

The Tampere University of Technology is located in Hervanta. After a brief general lecture on the University, laboratories and lecture rooms of a recently completed science building were toured. The facilities appeared to be quite good. The highlight of the visit was a tour of a new university building under construction. It was extremely interesting to observe design and construction practices as well as the use of building materials in the construction process.

William Cullen also toured buildings in the Helsinki area. of particular interest was the construction of a new facility for Helsinki's largest newspaper, "The Helsingin Sanomat." As with much new construction in Finland energy conservation is of primary importance. Buildings in Finland are having unique problems with the performance and durability of their external facades. An example is the Helsinki Cathedral; currently, the external surface is undergoing restoration. The condition and restoration of this building provided the subject matter for one of the Symposium papers. 


\section{FRANCE}

A formal program to exchange building research results and to coordinate research objectives has existed between France and the U.S. since 1969. Since then, the Centre Scientifique et Technique de Batiment (CSTB) has been CBT's primary point of contact. CSTB's main facility is near Paris, with other laboratories in Nantes, Grenoble, and Champs-sur-Marne.

In May 1977, a new five-year agreement on future cooperative research was signed between NBS and CSTB. In the realm of building research, the agreement centers on developing new program thrusts, contingent on resources and areas of mutual interest. The agreement identified a number of topical areas for joint programs over the next two years.

This joint CBT/CSTB program covers numerous activities, including complementary research, exchange of technical information, and also the exchange of scientists for short-term visits. For example, last year CSTB guest worker Jean-Noel Andre completed his research assignment at CBT and returned to Grenoble on December 1, 1976. The results of his studies on the effects of hot water on the corrosion of piping materials will be published as a journal article or a CBT publication. Likewise, CSTB's Philippe Eurin, Chief of the Physics and Materials Section, Grenoble, visited CBT in September 1976. The visit included a four-day stay, during which time he conferred with CBT's Geoffrey Frohnsdorff and his staff. Philippe Eurin was supplied copies of the Materials and Composites Section project plans for the coming year on non-destructive coating of metals.

In April 1977, a two-man team--including the IAT Acting Director, James R. Wright--went to CSTB to explore further exchanges and to view several promising new programs. 
This project deals with the corrosion of building water pipes from both untreated natural waters, representing various areas of France, and similar waters containing corrosion inhibitors. The research is a continuation of the investigation which Jean-Noel Andre began at CBT. The experimental apparatus, which is currently under construction, is a second generation version of the one located at CBT and includes a data-logging system.

\section{Corrosion of Rebars in Concrete}

A similar study was conducted at CBT a few years ago. That work served as a point of departure for this French study--precisely illustrating the value of a cooperative program such as this one. Here, several methods are used to measure corrosion, including electrochemical techniques and weight loss.

\section{Building Plastics}

A number of materials are under study. These include polyvinyl chloride (PVC), glass-reinforced polyester, and others. The chemical and mechanical behavior of these materials under exposure conditions are under investigation. For example, in determining the predicted performance of these materials, hydrochlorination tests are being used, employing thermal techniques. Photo-degradation studies, using ultraviolet radiation, are also under way. Mechanical properties such as impact, breaking load, and the like are also being conducted on plastic materials. These mechanical techniques, in conjunction with dynamic tests such as the swinging pendulum, are being used to study the properties and performance of glass reinforced polyester. In the area of sealants and gaskets, certain elastomers such as EPDM and (poly)-chloroprene are under investigation.

\section{Roofing}

Materials being studied include plasticized PVC, as well as petroleum asphalt modified with a styrene butadiene polymer. These latter chemicals are provided by Shell Oil Company, as well as Phillips Petroleum. It was reported that the asphaltic bitumen containing 10-15\% of the polymer appeared to be quite effective. Other studies in the roofing area involve the measurement of the properties of some insulating materials such as foam polyurethane and a rather new material in France, which was identified as a paper foam.

Acoustics: Sonic Booms

The French sonic boom facility is extremely interesting. The equipment can simulate a sonic boom at a frequency of about $10 \mathrm{~h} z$. This is generated by a large piston about 1.5 meters in diameter, which moves a distance of plus or minus 5 centimeters. This test room can accommodate walls or roofs of various types of construction, approximately $2 \times 3$ meters in size. The immediate benefit is to determine in simulated laboratory tests what effects supersonic aircraft, such as the Concorde, would have on construction. 
The traffic noise facility is contained in a single building. Its model landscape includes highways and expressways, as well as models of conventional buildings, constructed to scale. A series of noise generators are spaced at intervals in the highway, to simulate the noise of moving vehicles. Microphones are placed in various areas and identified by coordinates to pick up the highway noise. Then, traffic flow along the highway is controlled at various speeds and various distances. Noise barriers and shields in the form of buildings, canopies, trees and shrubbery can be placed at strategic locations to determine their effect on noise reduction. Each experiment is computer-controlled, and both the noise generation and the location of the microphones can be identified by coordinates.

Another unique facility studies noise transmission and propagation in buildings. The model is $1 / 3$ scale and is made of concrete and plexiglas.

\section{Structural Studies}

A structural research engineer from CBT, Emil Simiu, spent nearly six months at the CSTB laboratory at Nantes, France, last year working on part of a program to study wind engineering problems common to our two countries. The topics covered during his stay included the following:

\section{(1) Probability Distribution of Extreme Wind Speeds}

Common research efforts by CBT and CSTB on this topic have resulted in data heretofore unavilable, on load factors for wind-sensitive structures. The data jointly produced by CSTB and NBS, as "Sampling Errors in the Estimation of Extreme Winds" will be submitted to the Journal of the Structural Division, ASCE.

(2) Mean Wind Profiles in Suburban Terrain; Relation Between Wind Speeds at Airports and Over Built-up Terrain

Detailed results of measurements conducted by CSTB, as well as computer outputs and meteorulógical station data are now available. Extensive consultations on this topic between CSTB staff and CBT have been held for the purpose of proposing design parameters for the terrain roughness and the wind speed reduction factor over built-up terrain. A joint paper entitled "Mean Wind Profiles and Change of Terrain Roughness" and a Draft ISO Code section on this topic were prepared and presented at the Gothenburg, Sweden, meeting.

\section{(3) Effect of Change of Terrain Roughness Upon Wind Loads}

Extensive literature search and consulations led to the joint development of a simple procedure for making allowance for this effect.

\section{(4) Effect of a Terrain Slope Upon Wind Loads}

CSTB has made available detailed information obtained in fullscale measurements of an actual site. A theoretical model of flow over hills is now 
being developed. It is anticipated that these exchanges and future work by CSTB, the results of which will be conveyed to CBT, will allow the drafting of acceptable design provisions on this topic.

\section{(5) Wind Tunnel Testing}

Two projects have been conducted: the testing of a floating nuclear power plant and the testing of an inflatable structure. Based on these observations, Dr. Simiu was able to write a paper entitled "Wind Tunnel Simulation of Along-Wind Structural Response" to be submitted to the Journal of the Structural Division, ASCE.

(6) Pedestrian Comfort Under Wind Loads

CSTB has conducted substantive research and has assembled extensive documentation on this topic. Exchange in this area has been very illuminating.

\section{(7) Wind Code Provisions on Tall Building Design}

One purpose of the research program at the CSTB has been to develop code provisions on the design of tall structures for wind loads. Such draft provisions were presented at the London ISO meeting in a joint CBT/CSTB paper, "Dynamic Along-Wind Response of Tall Buildings".

Study of the "Agrément" System

CSTB holds the secretariat of the "Union Européene pour 1 'Agrément Technique dans la Construction" (European Union for the Technical Agreement in Construction) (members: Austria, Belgium, France, West Germany, Great Britain, Italy, The Netherlands, Portugal and Spain). The objective of the "agrément" is to provide information on new components and systems such as window frames, plumbing, partitions, floors (including precast and prestressed concrete), roofing, curtain walls, waterproofing and moisture control, and heating.

Their problems in technical evaluation and administration are similar to CBT's. Both groups are expected to prosper from consultation on this matter.

\section{Visits to Other Laboratories}

At the Champs-sur-Marne facility, research is underway on several new programs in the area of fire research, including heat transmission through partitions, and studies of toxicity of the air in the presence of fire. This research could make a solid contribution to parallel work underway at the NBS's Center for Fire Research.

At the Centre Technique Industriel de la Construction Metallique (at Puteaux), much promising work is continuing, especially on the plastic design of structures. Design procedures, including computer programs, are being developed that result in more economical (less conservative) designs than the AISC procedures. Further work covers composite structures, thin walled structures, 
and staggered truss systems. There too, computer programs are widely used, particularly in the area of off-shore platform structural designs. Likewise, much work is being done in the area of wind design and probabilistically defined loadings. Many of their research interests are similar to ours. It was agreed that CBT/CSTB will exchange publications, criticize each other's work, and otherwise cooperate on furthering of common research goals.

At the Centre Experimental de Recherches et d'Etudes du Batiment et de Travaux Publics (CEBTP), St. Remy-les-Chevreuse, Emil Simiu conferred with the head of the Aerodynamics Testing Branch. CEBTP has branches in various African countries and missions in Brazil, Guyana, and Iran . Main activities cover soils and foundation research, testing of materials, testing of structures (including full-scale in-fill masonry), physics and chemistry of materials (cement, concrete, paintings, plastics, corrosion, radiation), heating, acoustics and vibrations (including noise control), plumbing, and aerodynamic testing. Useful experimental techniques for evaluating combined wind and snow loadings were demonstrated, and pertinent literature has been made available to CBT.

Joint Publication

Three reports published by CSTB are being translated and published as NBS Technical Notes. They are: "Incomfort du au Vent aux Abords des Batiments, Concepts Aerodynamiques," "Methode de Prevision Par Calcul du Comportement au Feu des Structures en Beton," and "Acoustique."

As a result of discussions between the Director of IAT and CSTB in May, it was decided that joint activities over the next two years should cover the following areas:

- Exchange of scientific personnel on long-term and short-term assignments.

- Exchange of visits of building technology teams in areas of

1) general activities; 2) hospital and medical facilities;

3) housing; and 4) school construction.

- Exchange of visits of individual scientists and engineers.

- Exchange of ideas, skills, techniques, and procedures for attacking mutual problems in technical areas of buildings.

- Exchange of technical literature, including translation and distribution of selected papers. 


\section{INDIA}

Two members of the CBT staff--Edward O. Pfrang and Lawrence Galowin-attended the International Seminar on Low-Cost Housing in Madras, India. There they provided information to developing countries on the U.S. experience with the performance approach in evaluating innovative housing solutions, studied new housing developments taking place elsewhere in the world, and met with international housing experts.

They also spoke with India's Hitendra Desi, Minister of Works and Housing. Although India's housing problem is more serious than ours, unfortunately India lacks several essential resources. The Minister pointed out that he was convinced that in some ways, India is in a vicious cycle in that their people lack the housing they need to achieve a healthy environment. As a result, their people generally do not have the sufficient energy to build the very housing they need.

Although the Minister pointed out that the housing problem in any country is a social-economic problem as well as a technical one, in the main his country looked to CBT and the United States for technical support. He felt that India needed a great deal of technical input to meet the housing needs of its people. He acknowledged that the U.S. has the most technologically advanced building industry in the world and also is the world's most efficient builder.

V. Kandaswamy, of the Center for Housing, Building, and Planning of the United Nations, had interesting thoughts concerning the housing problem in the less-developed countries (LDCs). Chief of these was that housing is traditionally treated as a consumer good, not as a productive good. Thus, as LDCs attempt to develop, they give housing a low priority. As he sees it, however, housing is the key to productivity in a developing country. Until you can improve the health and strength of your working force, you have no chance of working your way out of poverty. Therefore, he is urging that LDCs devote a much greater proportion of their resources and capital to at least minimal housing as a mean of breaking the poverty cycle. 
At the Central Structural Engineering Research Center, on the outskirts of Madras, most of the work is directed at specific applied problems. The work appeared to be a suitable balance of experimental and analytical effort. The Indians are extremely interested in pursuing cooperative research with $\mathrm{CBT}$.

By participating in this international seminar on low-cost housing, CBT provided access for much of the world to U.S. building technology. It also provided input into our own program development, because most of the attendees at the conference looked to the U.S. and NBS for the technology for solving their own housing problems. In fact, most of the Middle Eastern countries now have ample capital available to them for overcoming their housing shortages. However, they lack technology, skilled labor, and building materials.

Upcoming cooperative work between CBT and India could involve: flat conductor cable systems for Indian wiring in buildings based on an Indian proposal to CBT; and continuation of sanitary plumbing drainage for high-rise buildings without a vent, at the Central Building Research Institute, Roorkee. 


\section{INDONESIA}

A CBT staff member, Noel J. Raufaste, participated as a group leader on a two-week survey of standardization and measurement services in support of Indonesia's building industry. This work was performed at the request of the Indonesian Institute of Sciences (LIPI) and funded by the Agency for International Development. Noel Raufaste was assisted by Zaini Djaprie, Inspectorate General of Indonesia's Ministry of Public Works and Electric Power.

The basic material for the survey was gathered at meetings with Indonesian building officials during June 1 to 11, 1977. After various papers reviewing the standardization, calibration, and measurement activities in Indonesia were presented, numerous visits were made to construction sites, manufacturers of building products, and executives in the industry.

Building technology is one facet of Indonesia's national needs which are usually expressed in terms of 5-year Development Plans. In 1969, the first such plan was enacted. It was aimed at improving a shaky political and economic environment. Priorities were placed on methods to stabilize the government. During the second 5-year plan (1974-1979) refinements were made to improve the quality of 1 ife; emphasis was placed on agriculture, mining, industry, electricity, natural gas, and oil exploration. The third 5-year plan will be more specific. The results of this CBT survey will be used to outline the nation's expectations in the realm of housing and construction.

Today, however, Indonesian building practices vary widely. There are few building codes and standards. And what few there are, are seldom enforced. Buildings are constructed following traditional methods (post and beam structures and thatch roof and walls), transitional methods (mix of the traditional with modern materials), and modern methods (adopting building designs from the western world). With the exception of imported industrial construction--to attract multinational investments, for example--building practices need improvement. 
Most of the residential buildings in Java, where 65 percent of the nation's 130 million population live, are constructed of brick and concrete block. Buildings on the other islands are usually made from timber. Java's inclination toward brick results from its forests having been cut down to rnake way for rice planting.

Manufacturers of building products generally fail to produce uniform (standardized) goods. Clay tile and bricks are examples. This is due in part to a lack of consistent standards and to lack of enforcement. The products are uneven in quality, shape, and cost. Concrete tends to be poorly made at the job site. Steel reinforcing bars have been known to be smaller than their identified size. For example, a 25-mm bar may in fact measure 20-mm or even $18-\mathrm{mm}$.

Improvements in Indonesian building practices can be attained with a new organization specifically formed to oversee building. This organization would serve as the national leader for a new system of building regulation. Specific recommendations to achieve a better built environment in Indonesia will be discussed in the forthcoming NBS survey of standardization and measurement services report. 


\section{ISRAEL}

The serious water drought in the western U.S. is bringing about strong efforts by CBT to draw upon the Israeli talents and experiences in alleviating water shortages. Part of this effort was represented by discussions between Lawrence Galowin, chief of CBT's Building Services Section, and representatives of the Israeli building research community.

In the past, joint research projects between Israel and the U.S. under P.L. 480 have had successful outcomes. During the past few years, a series of Bi-National science projects have been undertaken, under which both countries involved mutually share the cost of the research. One area of interest for future studies under this program is gas chromatography measurements of wastewater and treatment studies of wastewater. Both these studies are compatible with current CBT studies of community service system and water conservation studies. A second topic of interest covers test method development and improvements to solar collectors--since there are so many solar hot water supply systems in Israel.

The Standards Institute of Israel (SII) is the authorized center for specifications, standards, and testing of products. Their approval is indicated by one of two symbols that indicate a standard--or specification--approved item. The Minister of Trade has the authority to declare a standard as official law. The thrust is to gain compliance for economy, safety, and health. There are about 400 committees of about 20 representatives each (not all active) to draft standards. The Hydraulics Laboratory staff provides design aid to manufacturers to develop new plastic pipe components. They are actively developing research projects to expand beyond the existing testing activities base. The Israel Center of Water Works Appliances, at SII, generates specifications for domestic, agricultural, and industrial use.

At SII, a wide variety of purchased test equipment and specially built test devices are used. There is less dependence upon electronic instrumentation than is common in the U.S. For example, simultaneous tests on six watercloset tanks with dual flushing capabilities were controlled by fluidic timers and electrical solenoids to drive them for 50,000 operating cycles. 
Simplifications of ASHRAE and ASTM testing methods are adopted for laboratory testing because of limited funds available. A CBT exchange in seeking lower-cost standard test methods may be desirable in this area.

The PL 480 Plumbing Study completed at SII was discussed. The recommendation to have SII become an active participant in CIB W62 was accepted and that action was initiated through the 662 Coordinator. Agreement was obtained to cooperate in the consolidation of the PL 480 material into a joint report for presentation at a future CIB W6 2 meeting.

Currently, field test study of pressure regulators and flow regulators are underway with water savings indicated at 20 to $38 \%$ in apartments. Galvanized steel pipe is widely used with corrosion as the major problem being studied. Hot water heater corrosion is another problem area under active study. Installation practices for plastic water pipes are also being evaluated. Likewise, laboratory studies are underway to evaluate concrete, reinforcing rods, aluminum window frames, radiators, insulation, and solar systems (particularly corrosion in tanks), which are in wide use for hot water supply in Israel. They are concerned in all their endeavors with problems in undertaking the costly, complex standard tests as recommended by ASHRAE and ASTM.

At the Building Center of Israel, Tel Aviv, Lawrence Galowin met with Director Nahum Granot and three staff members to discuss their activities in providing and developing new housing. Currently the major concern is to provide for energy savings and better services in buildings. Central solar systems for apartment buildings are desired to eliminate the unsightly scatter of panels and tanks on roofs and balconies. One approach is to eliminate gravity-feed tanks with pumped systems to the hot water heater.

The new building developments in Jerusalem were cited as a very effective program. The project aims to coordinate the "ancient" appearance with the new housing and has conserved a Roman arch-covered road through the area. Shops are also being built to make the area economically practical-as a living area with services and businesses. Efforts to similarly improve the housing in the other Quarters cannot go forward now but serious considerations are being made for improvements to the water supply, drainage, and electrical services.

The Technion--Israel Institute of Technology, Haifa, is divided into two major parts: the Center for Building Research and the Environmental Engineering Research Center. The Center for Building Research is part of the organization known as Technion Research \& Development Foundation.

This is distinct from the academic functions since the Center contracts for work and functions through its laboratories to provide certification of building materials. Tests are based upon official or accepted standards. When approvals are made they permit manufacturers to label or mark their products for conformance to a specification. The laboratories have dealt 
mostly with structures and properties of materials. Sample markings of reinforced concrete rods, concrete blocks, and tiles were displayed.

The Environmental Engineering Research Center claims a significant capability developed over several years in applications of gas chromatography and mass spectrometry as a general method for determining presence of organics (distinct from the biological factors) in wastewater processing. Investigators are now preparing identification listings of trace amounts of compounds detectable throughout the intermediate steps of the water treatment process. Their decision to go toward a "fingerprinting" technique is shared with knowledge of new methods also under development in other countries (Ohio River pollutants identification research, Switzerland water studies). The wastewater facilities include a pilot plant to use chemical/physical/ozonation treatment methods. The sequence and interchange of the several treatment methods are under study to optimize the treatment process. 


\section{ITALY}

Italy's 1976 earthquake resulted in almost 1,000 deaths, left an estimated 70,000 people homeless, and caused damage estimated at about \$2 billion. To help assess the damage, a CBT staff-member, Emil Simiu--then on a long-term research assignment in France--was asked to join a Task Force studying the problem shortly after the disaster struck.

To contribute to the rehabilitation of the earthquake-stricken regions, the U.S. Congress allocated $\$ 25$ million. The U.S./Italy earthquake disaster relief program, supported by these funds, was to be based on actual need as identified by this Task Force. Further, this expenditure had to be consistent with U.S. legal requirements, including a limitation on the use of U.S. public furds for humanitarian assistance programs only. The funds could not be used for the restoration of works of art or the rebuilding of monuments of artistic or historic value unless such rebuilding served humanitarian assistance purposes, as in the case of public buildings that can be used as emergency shelters. The Task Force did, however, provide information on, and facilitated contacts with private U.S. groups interested in contributing to the restoration of works of art, churches, and villas.

Further complicating this task was the knowledge that previous experience in Italy, notably in Belice, Sicily, has shown that emergency settlements, even if not planned to meet long-term needs, may tend to perpetuate themselves. The over-all rehabilitation effort was to be planned with a view to avoid such developments. For example, the temporary dwellings that were needed before the advent of the cold season in September to house the tens of thousands of persons now living in tents were to be designed in manner compatible with long-term needs and should therefore, allow for subsequent esthetically and economically legitimate uses.

At a tent city ("tendopoli") near Osoppo, the tents, as we 11 as the sanitary and cooking facilities, were supplied by the Italian Army, which was also responsible for managing the camp operations, food supply, disinfection, and security. The discipline and cleanliness in the tent city were inpressive. 
The effects of the earthquake in Majano were catastrophic. A mediumrise apartment building with reinforced-concrete frame structure collapsed; almost 50 persons died. A second medium-rise apartment building sustained very severe damage, including floor displacements of as much as $0.20 \mathrm{~m}$. The frame columns were provided with only nominal reinforcement and stirrups were rare $(0.40 \mathrm{~m}$ o/c or so). Several columns failed near the joints by crushing of the concrete and buckling of the reinforcing bars. The frames were filled with masonry brick walls which increased the rigidity of the structure and, thus, the magnitude of the lateral loads. The frame-masonry wall system is not capable of composite action, the shear capacity of the masonry and the frame-masonry bond capacity being too low. Fortunately, the building did not collapse, owing to redistribution of vertical loads and to possible relief of damaged columns by adjoining masonry. Press reports indicate that the designers and builders of the two medium-rise buildings have been indicted on several counts of substandard design and construction. The inspection of the damage patterns revealed that modern structures would have resisted the earthquake forces successfully in most cases, had seismic provisions been incorporated in the design. 


\section{JAPAN}

The US-Japan Cooperative Program in Natural Resources (UJNR) was established in 1964 by the US-Japan Cabinet-level Committee on Trade and Economic Affairs. Its purpose is to exchange scientific and technological information that will be mutually beneficial to the economy and welfare of both countries.

This year was the ninth annual meeting of the UJNR "Panel on Wind and Seismic Effects," which was chaired by Edward 0. Pfrang of CBT. The annual joint meeting of this panel is designed to exchange technical information on the latest research and development activities within governmental agencies of both countries. Thirty-three technical papers were presented this year, including "Transferring the Technology of Wind-Resistant Buildings to Developing Countries," by Noel J. Raufaste of CBT.

In addition to the technical papers, seven task committees and a resolution committee met and developed plans for continuing cooperation between the U.S. and Japan in the areas covered by the Panel. The task committees are:

- Task Committee on Strong Motion Earthquake Observation

- Task Committee on Large-Scale Testing Program

- Task Committee on Repair and Retrofit of Existing Structures

- Task Committee on Evaluation of Structural Performance

- Task Committee on Land Use Program for Controlling Natural Hazard Effects

- Task Committee on Life Line Systems

- Task Committee on High Speed Wind Data 
The National Science Foundation is funding a program under the auspices of the UJNR for the development of plans for large-scale structural testing to be carried out jointly by the U.S. and Japan. CBT will be playing a inajor role in these plans.

The Japanese Government has developed a new program by which it is able to fund U.S. Government researchers coming to Japan to participate in joint research projects. Robin McGuire of the U.S. Geological Survey, a temporary member of our UJNR panel, is the first participant in this program in the construction area. CBT has been asked to consider potential candidates for next year under the program. In addition, the Japanese have agreed to explore methods by which they could send their researchers to the U.S.

Proceedings of this Ninth conference will be published prior to the Tenth Joint Meeting scheduled for May 1978. Last year also saw the publication of the conference proceedings from the Seventh and Eighth Joint Meetings, as summarized below:

The Seventh Joint Meeting of the US-Japan Panel on Wind and Seismic Effects was held in Tokyo, Japan on May 20-23, 1975. The exchanges dealt with extreme winds in structural design; assessment and experimental techniques for measuring wind loads; dynamics of soil structures and ground response in earthquakes; structural response to wind and earthquake design criteria; disaster mitigation against natural hazards; and technological assistance in developing countries (NBS Special Publication Number 470).

The Eighth Joint Meeting of the Panel met in Washington, D.C. on May 18-21, 1976. The topics included wind effects on structures; extreme winds for structural design; ground motions and instrumentation; seismicity and earthquake risk; lessons learned from recent natural disasters; seismic effects on structures; design of nuclear reactor facilities; and a special session on the Guatemala earthquake (NBS Special Publication Number 477).

In September 1977 Edgar Leyendecker, structural research engineer of CBT's Structures Section attended a planning session in Tokyo of a National Science Foundation sponsored program on large-scale testing of structures. The purpose of this task committee meeting was to develop with the Japanese a cooperative program on full-scale testing of buildings. 


\section{PHILIPPINES}

Under an Agency for International Development (AID) project, the Center has been developing improved wind-loss design criteria for low-rise buildings. The results of this work are applicable to wind-prone nations worldwide. A significant amount of this research was undertaken in the Philippines and assistance was provided by professionals and technicans from the University of the Philippines and from the Philippine Weather Bureau.

The research is now complete, with the publication of CBT's five-volume technical research report, BSS-100, Building To Resist the Effect of Wind, a shorter user-manual, entitled 43 Rules -- How Houses Can Better Resist High Wind, and a large poster emphasizing improvements that can be made to existing houses and directing citizens of wind prone countries to the location of more information on wind-resistant building practices. These latter two materials will be translated by and for use in other nations.

The CBT research data have led to revisions of the Philippine National Building code and are used as text material for engineering courses at the University of Engineering and Technology, Dacca, Bangladesh (a participant in this research project). The Center's 16-mm color/sound movie on the results of the research was awarded first prize at the 1976 international film competition in Rome. The success of this project is largely due to the CBT Structures Section, and in particular to Richard D. Marshall, the principal investigator.

During late September 1977 Richard Marshall presented a paper at the Joint U.S. - Southeast Asia Symposium on Engineering for National Hazards Protection. He discussed recent developments in the formulation of design wind loads. This opportunity to visit the Philippines gave him a chance to discuss with staff from the University of the Philippines and the Philippine Weather Bureau the experimental results from the CBT's High Wind project and to prepare for their widespread application to housing designs at a later date. 


\section{POLAND}

Porter Driscoll, Manager of CBT's Design and Construction Technology Application Program, was the chairman of a group of building executives who presented in Warsaw a seminar on automated building technology. The project aims at applying this branch of U.S. technology to Eastern European building needs. The seminar participants were exposed to the latest ideas in administration and financing of Poland's massive housing and rebuilding program.

Large areas of Poland, particularly Warsaw, were severely damaged during the 1939-45 war. Since then, the Polish design and construction industry has been continuously employed in replacing housing and commerical and industrial buildings. Whole sections of Warsaw have been planned and rebuilt; the Poles now enjoy an international reputation as planners. It is through this planning ability that design and construction enterprises have been established in emerging countries. At this and subsequent meetings with executives of Budimex, the Polish foreign trade building enterprise, the specific use of American technology was examined both in groups and individually.

Poland's building research is conducted at the Center for Building Systems Research and Development. This organization performs research underlying the establishment of standards or "normatives" (both minimum and maximum) established by various elements of the government. The Ministry of Building and Building Materials establishes the design and construction "normatives" for town, city, and regional planning. The Director feels his organization is very closely linked to reality because it must establish and modify over time those standards which will provide wise and efficient allocation of limited resources to meet a tremendous need.

In the past 15 years, $4.3 \mathrm{million}$ flats have been built to the standards established by this organization. Generally, research there begins with the identification of individual and group needs and the analysis 
of how these needs can be met within the resources available. In addition to the standards for housing and related housing amenities, standards are also established for schools, day-care facilities, health-care facilities, and retail facilities--based on the populations they serve.

In the area of financing, the Ministry of Building and Building Materials has manipulated real demand by establishing different downpayments and different loan periods for different types of housing. For example, an apartment in a multi-family dwelling qualifies for an $80 \%$ loan repayable over a period of 40 years, whereas a single-family detached house qualifies only for a $50 \%$ loan that must be repaid over 25 years. This revision has changed the form of housing in Poland, which prior to World War II had over $45 \%$ single-family detached houses. Now a very high percentage of production is grouped mid-rise multi-family buildings. However, the Poles' love of the is at least partially met by the creation of long-term allotments for gardening, remote from the apartment buildings.

In addition to determining "what" should be built, a great deal of attention was paid to "how" to build it. Much use is being made of building systems similar to those in the other Eastern European countries. The systems are quite often large precast concrete panels and are combined with prefabricated "core" units for bath and kitchen assemblies. Additional techniques include "tunnel" forming and large panels cast in-situ.

As the fiscal year came to a close, discussions were just underway for Poland to approve a new cooperative research venture between $\mathrm{CBT}$ and the Building Research Institute of Poland (Instytut Techniki Budowlanej). The subject of this first--of what is hoped will be a series of such projects-will be the development of improved techniques for the non-destructive testing of concrete. 


\section{ROMANIA}

Two CBT researchers--Charles Culver, Manager of CBT's Disaster Mitigation Program, and S. George Fattal, a structural research engineer--of the Structures Section visited Romania after the earthquake of March 4, 1977. They were part of a U.S. delegation assessing the damage and making suggestions for repair and reconstruction.

This post-disaster investigation provided an opportunity for NBS to contribute technical expertise in response to a specific request from Romania. It also was an opportunity to further observe the behavior of full-scale structures subjected to earthquakes. The data will be particularly useful in identifying research needs for rehabilitation of similar structures in the eastern United States. The CBT staffers also made contact with earthquake researchers at the Romanian Building Research Institute and opened channels for exchange of research data on building performance.

This investigation was recently acknowledged by AID's Administrator John Gilligan, in a letter to Secretary Juanita Kreps, for the excellent support provided by $C B T$, and who requested strengthening AID/NBS activities under more formal arrangements. NBS Special Publication 490, Observations on the Behavior of Buildings in the Romania Earthquake of March 4, 1977, is available for distribution. 


\section{SPAIN}

In September 1977, Edward O. Pfrang, Chief of CBT's Structures, Materials, and Safety Division, met in Madrid with Prof. del Campo of the Laboratorio Central de Ensayo de Materiales de Construccion (LCEMC) and other laboratory staff members to finalize the first year's cooperative effort between LCEMC and CBT under the U.S./Spain Joint Agreement on Science and Technology. To date, it has been agreed that the first joint study will cover "Factors Affecting Corrosion of Steel in Prestressed Concrete Structures."

The Laboratorio Central de Ensayo de Materiales de Construccion (LCEMC) consists of eleven departments. Two, the Secretariat and the Administration, are concerned with general activities and public relations. The remaining nine departments are concerned with specific technical areas covering the broad field of testing construction materials and structures. T'inese departments are: Physics and Electronics; Inorganic Chemistry; Organic Chemistry; Mechanical Testing and Concretes; Theoretical Studies of Structures; Experimental Analysis of Structures; Experimental Analysis of Conduits and Drainages; Special Studies; and the Mechanics Shop. Work in the LCEMC is accomplished by teams formed through cooperation between the sections of the different departments.

The laboratory carries out mostly problem-solving work aimed at immediate application. They do quite a bit of work with elastic models for structural analysis. But most of their structural work, in addition to the modeling, is relatively small-scale. They do not have particularly large test capabilitie in the structural area. They generally tend to use self-contained structural test frames. They are, however, doing a fair amount of full-scale work on large, prestressed concrete pipes. They are also in the process of carrying out model studies of proposed dams not only for spain, but also for the use of being built in other countries. 
the materials areas, most of their work relates to either concrete, cement, inforcing steel or masonry. The most critical problem at this time appears to the corrosion of prestressed reinforced concrete pressure pipes. They have A a number of failures with these pipes and they have now become suspicious all prestressed concrete in Spain. The Spanish are having a number of Iailures th aqueducts bringing in water to their major cities. Madrid, in fact, has lost 3 water supply on a few occasions. This may be a profitable area for future int studies. 


\section{SWEDEN}

In May 1977, Paul R. Achenbach CBT's Senior Research Engineer, attended as a representative of NBS and as a member of the U.S. delegation, a Seminar on Building Research Policies sponsored by the Committee on Housing, Building and Planning of the European Commission for Europe. The Government of Sweden hosted the seminar, which was held at the new facilities of the Swedish Building Research Institute in Galve, about $180 \mathrm{~km}$ north of stockholm. An auxiliary function was to visit several building construction sites in Gavle and Stockholm to observe Swedish practices in renovating old residential units and in building for detached housing apartments.

Representatives from the following countries participated in the seminar: Belgium, Canada, Czechoslovakia, Denmark, Finland, France, both Germanies, Hungary, the Netherlands, Norway, Poland, Portugal, Sweden, Russia, the United Kingdom, the United States of America, and Yugoslavia.

Four working sessions were held, with a half day each allotted for the papers of the rapporteurs and discussion by the delegates. The general objective of the seminar was to discuss ways and means of planning, organizing, coordinating, and financing building research at the national level.

In Gavle, Paul Achenbach visited the subsidized housing for employees of the Sandvik steel plant. Sandvik originally built this housing for its employees: first, one-story buildings containing apartments of one room and kitchen; later two-story buildings with 8 apartments of similar size. The entire housing area was acquired by the municipality of Gavle in 1969. Most of the old buildings were demolished, but a few have been renovated for historical purposes. About 700 new apartments have been built, with groups of 30 to 40 centered around a courtyard that contains a laundry room and meeting hall. No automobile traffic is allowed in the area. 
A few blocks of old Gavle have been restored, near the center of town. However, renewal has been slackening in recent years. Surveys indicate that only about 1500 units out of a total of 38,000 in the municipality are in need of renovation to bring them up to modern dwelling standards.

A new development, Satra, which houses 11,000 people was also visited. The development has a mixture of housing types--multi-family stuctures of four stories, and 2-and 3-story sections with both rental and tenant-owned options. There are also single-family houses in one-story and 2-story row house styles. Every sixth dwelling in this development is a rented row house. Old age pensioners and young families with small children have often chosen this latter form of dwelling.

Another development, Andersberg, is Gavle's newest community and is about $2.5 \mathrm{~km}$ from city center. The city owns all of the land. Construction started in 1973 and will be completed in 1978, when about 2300 dwelling units will house approximately 5000 inhabitants. The mix of dwelling types is similar to that for Satra except that a considerable number of apartments are incorporated in large 5-story buildings. A group of l-family houses has also been allocated for research purposes. Thirty households have been invited to participate in the planning and selection of house types. In addition each household can collaborate with the architect in designing its dwelling.

At two sites--Trasten and Pyramiden--in the center of Stockholm, rehabilitation of old 5-story flats were being carried out in block-size areas. The buildings were from 60 to 85 years old and had not contained indoor plumbing nor elevators. They had used fireplaces or the Swedish form of "Kacheloven" for heating selected rooms, and most did not have domestic hot water. The walls and floors appeared to be in very good shape structurally--there were no cracked walls or sagging--perhaps because most of Stockholm is underlaid with rock. In general, walls and floors were simply given patching and refinishing. Three large buildings were demolished because they were supported by pilings that had decayed. Walls were of very thick masonry, 50-60 cm thick, with no insulation.

Many apartments were enlarged; 419 original apartments were renovated into 239 larger apartments. Apartments were of mixed sizes, ranging from 1 room and kitchen to 5 rooms and kitchen. Hot water heating, using radiators with small tubing, was installed with hot water being supplied from a central plant. Modern baths and kitchens were installed as were elevators wherever there was enough space. Single windows were replaced with double windows; new wiring was installed, partly hidden and partly surface. Old tile roofs were replaced with ridged metal roofs.

Rents after renovation are equivalent to those for new housing at 125 crowns $/ \mathrm{m}^{2}$ per year (equivalent to about $\$ 250 / \mathrm{mo}$. for a $1000 \mathrm{ft}^{2}$ house). This is about 3 to 4 times the pre-renovation rent, but tenants can get subsidies ranging upward to the full cost, depending on their financial condition. The buildings will be occupied by a mixture of subsidized and non-subsidized families. 
Stockholm has about a half million non-modern and semi-modern dwelling units. City plans call for renovation of about 5000 units per year.

The cost of heating and electricity are not paid by subsidy. The total cost of heating for the block is pro-rated to the tenants on the basis of floor area.

The seminar attendees also visited four new-town type developments on the perimeter of Stockholm about $16 \mathrm{~km}$ from the center of the city. These four towns are planned to contain 13,200 dwelling units and 33,000 people by 1979. The population in 1977 is about 27,000. Two of the towns are completely occupied. One, Kista, will have 3500 units, and is only about half completed at present. The city subway adjoins the developments.

In the Master Plan for the entire area, $32 \%$ of the dwelling units will be one and two-story buildings, $46 \%$ will be in 3-to 6-story structures, and $22 \%$ will be in 9-to 13-story structures. In Kista, several different styles of building are being constructed to provide varied architectural views to the occupants--terraced buildings, rowhouses, and a starshaped plan with units radiating from a central entrance.

In Kista, the buildings interior partitions are reinforced concrete and loadbearing. The outer walls, made of air cell concrete with exterio stucco, serve as curtain walls. Windows are triple-glazed, one large section fixed, and a smaller section the casement type with gasketed meeting surfaces. Buildings are hot-water heated from a central plant. A pneumatic trash collection system serves the entire area, but the waste is taken from the central point to another location for incineration and power generation.

About $41 \%$ of the dwelling units comprise two rooms and kitchen or less, $37 \%$ comprise 3 rooms and kitchen, and $22 \%$ contain four rooms and kitchen or more. About $10 \%$ of the dwellings are designed for pensioners, and about $11 \%$ of the population will be 60 years of age or older. About 800 units will provide for the owner to make a contribution to the house construction. About 1000 one-and two-story houses will have their own gardens and ground-level entrances.

All of these developments involved competitive designs and proposals by Architectural Engineering firms, with awards being made to those judged to be best. The City government is making great efforts to make the new towns more liveable, since their experience with the generation of similar developments in the 1960's indicated that designs were too stereotyped.

Rents generally cannot exceed 150 crowns $/ \mathrm{m}^{2}$ per year. On this basis the monthly dollar cost would be about as follows:

$$
\begin{array}{lll}
1-\text { room \& kitchen } & \$ 150 / \mathrm{mo} \\
2-" & " & 160-195 / \mathrm{mo} \\
3-" & \text { " } & 230 / \mathrm{mo}
\end{array}
$$




$\begin{array}{ccc}4-" 1 & 1 & 265 / \mathrm{mo} \\ 5-" 1 & " & 310 / \mathrm{mo}\end{array}$

Similarly, in September of 1976, William C. Cullen, Assistant Chief of CBT's structures, Materials, and Safety Division, met with members of the Swedish building community. His first contacts were with corporate executives of a consortium of firms that supply building material to Scandinavia. Discussions included the general areas of marketing, performance, application and technical aspects of building materials both in the U.S. and European countries. The contributions of CBT in furthering the application of the performance concept for roofing, including the impact of performance criteria on European roofing, were particularly noted.

In Lund, Sweden, William Cullen discussed critical roofing problems--such as cracking under heavy loads of ice and snow--with technical personnel.

In Stockholm, William Cullen met with staff members of the National Board of Physical Planning and Building, Ministry of Housing and Physical Planning of the Swedish government. The primary function of that office is to provide guidelines for housing policy in the form of proclamations and regulations in accordance with the resolutions of the Riksdag (Swedish Parliament) and the government. This government organization is the ultimate appeal authority concerning buildings and building regulations. And it differs from CBT in that it publishes mandatory standards for the industry to follow--rather than just the technical support to a variety of codes and standards.

James Wright met with Professor S. G. Bergstrom, Director of the Swedish Cement and Concrete Research Institute. The purpose of James Wright's visit was twofold: (1) to visit the laboratories of the Research Institute and learn more about their research programs on the performance of concrete in building structures; (2) to visit Professor Ingemar Hoglund of the Royal Institute of Technology. Professor Hoglund is a foremost Swedish expert on energy conservation in buildings and solar energy.

A number of these areas are of interest to the Inorganic Materials program of CBT, particularly those dealing with early strength of concrete, the corrosion of reinforcing bars in concrete, and polymer and fiber reinforced concrete. A member of the CBT staff (Thomas Reichard) serves on a RILEM technical committee under Professor Bergstrom which is making an indepth study of the performance strength of concrete at an early age.

James Wright was particularly interested in the work that the Research Institute is doing on application of the performance concept to the performance of concrete in a finished building. This research program grew out of the RILEM/ASTM/CIB Symposium held in Philadelphia in 1972 on the Performance Concept. The aim of the Institute's work is to write performance specifications and standards for ultimate use in building codes to replace prescription specifications currently in use in Sweden, and most other countries as well. The results of the Swedish research 
have reached a stage where they are now going into a revision of the building codes. This work will be of direct benefit to the Center for Building Technology, NBS, as it works with both Federal builders, builders in the private sector and building code officials to develop performance-based standards for building codes in the United States.

The meeting with Professor Hoglund of the Division of Building Technology, Royal Institute of Technology, was to discuss energy conservation research and solar energy techniques that are being carried out in the Institute as well as in practice in Sweden. Sweden imports all of its oil and has a severe winter climate. Therefore, energy conservation and efficient thermal performance of whole buildings has been reflected in building practice in this country for many years; long before energy was considered a problem in the United States. Consequently, many of the current building practices in Sweden, such as double glazing of windows to reduce heat loss by 50 percent, have been a part of their building regulations for many years, but are seen in the U.S. as new practices yet to be fully implemented. To give some measure of the state-of-the-art, Swedish building codes are now being revised to require triple glazing of windows rather than double glazing. The basis for the additional cost and effort for triple glazing as compared to double is an economic one which has been developed from a highly sophisticated life-cycle costing technique.

Professor Hoglund is interested in the work CBT is doing in solar heating and the use of solar energy for domestic hot water heating. In spite of its northern latitude, Sweden wants to explore the potential for the use of solar energy for these purposes. 


\section{USSR}

The U.S./U.S.S.R. Agreement on Cooperation in the Field of Housing and other Construction was signed in Moscow in 1974. The purpose of the Agreement was to facilitate information transfer between the U.S.

and the U.S.S.R.

Following this agreement, a Memorandum of Implementation was signed by the Secretary, U.S. Department of Housing and Urban Development, and the Deputy Chairman of the Council of Ministers for Construction Affairs (Gostroy, U.S.S.R.). The Memorandum of Implementation formally established six working groups. CBT has been involved in two such groups, "Building Materials and Components" and "Building Design and Construction Management."

Cement Studies

In November of 1976, Geoffrey Frohnsdorff, Chief of CBT's Materials and Composites Section, traveled to the U.S.S.R. as part of a working group studying cement production and chemistry. An early stop was at the Podulsk facility of NIIcement, the All-Union Cement Research Institute. NIIcement is the main national research institute dealing with problems of the cement industry; it carries out scientific research, develops equipment for cement plants, and trains cement specialists. The Institute has a staff of 950 in Podulsk, of which 400 are researchers in the 13 laboratories (total staff 700) and an additional 250 are in the pilot plant. NIIcement coordinates the activities of Giprocement (the Al1-Union Scientific Research and Design Institute of the Cement Industry) in Leningard and Yuzhgiprocement (the Southern Al1-Union Scientific Research and Design Institute of the Cement Industry) in Kharkov; its work is also closely coordinated with that of the National Academy of Sciences of the U.S.S.R. Special attention is paid to increasing the outputs of high-strength cements, expansive cements, and decorative cements and to converting wet-process cement plants to the dry process or to combined processes for the manufacture of cement and other products. They hope to be able to draw on U.S. technology in these and other areas through the cooperative agreement. Individual laboratories visited 
in the Institute were devoted to slag formation, clinker burning, refractories, fine grinding, and cement plant automation and control.

Yuzhgiprocement employs about 1,300 persons, of whom over 1,000 are university graduates. The largest part of the activity is cement plant design, but research on cements and cement manufacture is carried out in the laboratories and pilot plant of the Institute. The Institute has been responsible for the design of about 50 cement plants, which account for about half of the U.S.S.R's cement production. The design group works on new plants and the improvement of existing plants. New plants usually have capacities in the range of 2.5 to 3.5 million tons per year. Research on slags and slag cements was discussed; the Institute has recently developed rapid hardening and super rapid hardening slag-portland cements. They also produced, and obtained a patent on, sulfate-resistant slag-portland cements that can be used in aggressive waters containing as much as 4,000 milligrams of $\mathrm{SO}_{2}$ per liter. MchedlovPetrosyan discussed research on new types of portland cement that had been carried out at the Institute. Cements of high reactivity have been prepared by burning at lower temperatures than were usual for clinkering. This has implications for energy conservation and for prolonging the life of kiln linings. Mchedlov-Petrosyan's labs were interesting for their application to clinker characterization of unusual techniques such as infrared spectroscopy and ESR in addition to the more usual methods such as $\mathrm{X}$-ray diffraction and thermal analysis.

The Balakleya Cement Plant is about $70 \mathrm{~km}$ south of Kharkov. It is one of the largest cement plants in the Soviet Union and has an annual capacity of about 3.5 million tons. The plant began operations in 1963 and it has been expanded three times since then in accord with designs drawn up by Yuzhgiprocement. The plant is impressive for the size of its equipment although it did not appear to be as well laid out for efficiency of operation as many modern plants in the U.S. Nevertheless, it demonstrates high levels of engineering and manufacturing capabilities. The plant manufactures two types of portland cement clinker and makes six types of cement.

In Leningrad are the laboratories and pilot plant of the Giprocement Institute, the Al1-Union Scientific Research and Design Institute of the Cement Industry. This is a large organization with similar functions to those of Yuzhgiprocement, though serving a different area of the country. Although the major part of the Institute is the Design Department, the Scientific Research and Pilot Plant departments are substantial, with at least 230 people between them. There are 14 technical laboratories. These include two for studies of clinker forming processes, two for studies of grinding and mixing of raw materials and cements, and other labs for physical and chemical analyses, physical and mechanical testing, refractory problems, dust collection, and economic production. Current work of the laboratories includes studies of new cements for oil and gas wells; the use of high voltage discharges to promote clinkering; the simultaneous manufacture of phosphorus, alumina, and high-quality portland cement; and 
fluxes for use in the clinkering process. Overall, the Institute's laboratories appeared to be well-equipped though they lacked an electron microscope.

The Institute of Silicate Chemistry, Leningrad, has a staff of about 400 and has two main departments--one studying silica and high-temperature reactions of refractory oxides, and the other studying solid-state processes. In the cement area, they are studying solid solutions of tricalcium aluminate and the effects of the dissolved oxides on the rate of hydration. A large range of techniques is used in the studies, including $\mathrm{X}$-ray diffraction, scanning and transmission electron microscopy, electron microprobe analysis, calorimetry and DTA. Other studies cover the earliest stages of hydration of calcium aluminate using single crystals grown in the laboratory.

At Giprocement, in Leningrad, meetings were held with Dr. Olesov, Director of the Institute, and members of his staff including Dr. Egarov and Dr. Danjushevsky. They spent some time answering questions from the U.S. team relating to the use of slag and fly ash in cements and concrete, the use of fluxes in cement manufacture, and general questions about the cement industry in the Soviet Union. Ultimately, discussion turned to possible areas of cooperation. Common areas of interest were in methods for the analysis of cements and raw materials and research on hydration processes, but possibilities for cooperation in research on manufacturing processes were recognized as being less certain because of the structure of the U.S. industry.

The Scientific Research Laboratories of NIIcement are situated in an old two-story house within the Moscow city limits. The staff of 26 is under the direction of Dr. Malinin. The emphasis is on basic research on cements with little concern about direct application to cement manufacture. Although the laboratory facilities were primitive, the laboratory was well-equipped. Most of the usual equipment for cement research was available including an X-ray diffractometer, DTA and TGA equipment, a transmission electron microscope, atomic absorption, flame photometers, light microscopes, an emission spectrograph, and an isothermal calorimeter. of particular interest was a five-channel $\mathrm{X}$-ray diffractometer for rapid analysis of multi-component mixtures such as cements and a polarograph used in studies of the liquid phase in cement hydration. Activities of the laboratory included quantitative phase analysis of cements and related materials, studies of microstructural changes during the hardening of cement, and studies of the mechanisms of cement hydration.

VNIIZhelezoBeton, Moscow, is the All-Union Scientific Research Institute for Reinforced Concrete. It focuses on concrete for industrialized construction. Major laboratories in the Institute are devoted to the development of technology for in-plant manufacturing of concrete products and stuctures; the production of industrialized housing; joining and welding; the production of pipes and reinforced pipes; the manufacture of prestressed reinforced concrete and railroad ties; and ordinary concrete including curing at high temperatures. Also, NDE is used for control, automation, and optimization of properties of concrete mixtures. Among the most promising and popular NDE methods were ultrasonics and radioisotopes. National 
standards have been established for use of several methods. They are now working in a new direction, which is the application of ultrasonics to forecasting the strength of joints and structures.

In general, exploratory visits such as this help both nations uncover those areas where each is likely to benefit from cooperation. In Russia today, the magnitude of the Soviet research effort in cements and the use of large pilot plants are impressive. The technology of blended cement manufacture and use, as well as methods of cement analysis are both likely candidates for cooperation.

\section{Housing Research}

In May of 1977, Harry E. Thompson, Deputy Director of CBT, traveled to the U.S.S.R. as part of the joint working group on "Building Design and Construction Managment." During that time he participated in discussions with Soviet experts on Norms and Standards, Terminology, and Space Planning. The American delegation consists of Federal officials and representatives of the architectural/engineering industry throughout the U.S.

One of the larger Institutes visited was the Central Research and Design Institute for Dwellings. This Institute has three Divisions (Research, Design, and Industrial Technology) with approximately 1,000 employees in each. Fifteen Republic (State) Institutes are under this Central Institute. They cover all building types, urban planning, and site planning plus experimental research and testing and prototype design. The Research Division is primarily working in applied technology similar to CBT (architectural, sociology, climate/health, building technology methods, structural engineering, mechanical/electrical, modular coordination/ standards, and testing laboratories).

Another Institute visited was the Central Research and Design Institute for Industrial Buildings, which also has fifteen Republic Institutes under its direction. While in Minsk and Leningrad the Republic Institutes were visited. These are very large units doing all of the design and construction for the industrial government agencies operating in the Republics.

In Moscow, the Research Institute for Building Physics has 16 laboratories doing work in acoustics/noise, thermal engineering, natural and artificial lighting, and building climatology. They have a new anechoic chamber which has three levels and is much larger than NBS's.

The U.S. delegation also toured a sprawling Soviet facility set up to mass-produce precast concrete sections for housing being built in connection with the Moscow Olympics in 1980.

In June 1977, Richard A. Symuleski of CBT's Building Services Section travelled to Moscow and Leningrad to review Soviet water and wastewater treatment technology and to discuss future collaborative studies. 
Based on this tour, it would appear that the application of innovative technology for water and wastewater treatment is proceeding at a slower pace in the Soviet Union. The singular exception to this is the modern ozonation facility built by the French for the water supply for Moscow. Nutrient removal in wastewater treatment and chlorinated hydrocarbon and virus removal in water treatment, while of major interest in the U.S., are not high-priority issues in the U.S.S.R. Major Soviet concerns appear to be focused on the design and engineering of simple factory fabricated components for use in small towns and worker villages in remote regions. Inspection of several facilities showed an orientation for labor intensive versus automated process control.

Soviet technologists appear to be well acquainted with new developments taking place in the West; but due to their orientation, this knowledge is primarily of theoretical rather than operational aspects of the technology.

Of potential value to the U.S. community, is the application of standardized design elements for water and wastewater treatment plants. A crude analogy for descriptive purposes would be the nationalization of the package treatment plant industry in the U.S. What needs to be learned is how design criteria are developed on such a large scale and the fabrication and assembly technologies that have been developed to permit large-scale implementation.

Joint cooperation in this area should continue with primary focus in the initial stages on acquainting U.S. technologists with the standardized design concept used in the U.S.S.R. This would also permit a closer examination of other aspects of Soviet water and wastewater treatment technologies. The differences in priorities and capabilities in the U.S.S.R. make the identification of other areas of joint cooperation very difficult at this time. 


\section{INTERNATIONAL ORGANIZATION MEMBERSHIPS}

In addition to individual research agreements with other nations, CBT also maintains a presence in a number of multinational professional research groups. Here, the aim, as always with CBT activities, is to foster the progress of building technology, to note changes in codes and standards the world over, and to bring the best foreign building research to the U.S. Last year's activities along these lines are discussed on the following pages. 


\section{CEB}

Edward 0. Pfrang, the CBT liaison representative to the Comite EuroInternational du Beton (CEB), met with Andrew Short, President of CEB at the Building Research Station, Garston, Watford, England to discuss and coordinate future activities. This collaboration with CEB will involve CBT more deeply in the developments of international codes of practice for building design and standards for reinforced concrete.

Since the end of World War II, CEB has become the dominant institution in Europe for technical cooperation in the area of concrete. It has been sufficiently successful in this area so that it is now being given a broader charter which covers all general structural design considerations. To obtain this broader charter, CEB has developed working agreements with such organizations as:

European Economic Community (EEC)

United Nations Economic Commission for Europe (ECE)

International Organization for Standardization (ISO)

European Committee for Standardization (CEN)

International Federation for Prestressing (FIP)

European Convention for Structural Steel Work (CECN)

International Council for Building Research

Studies \& Documentation (CIB)

International Union of Testing and Research Laboratories for Materials and Structures (RILEM)

International Association for Bridge and Structural Engineering (IABSE) 
In the last few years, $C E B$ has also gained the cooperation of several European countries, most notably the Soviet Union. An organizational tie has now been developed with the Eastern European Common Market through their Council for Mutual Economic Assistance (CMEA) and through its standards organization. Similar ties have been developed with the Nordic countries through their standards organization, the Nordic Committee on Building Regulations (NKB). In addition, Canada and Mexico are also members of $\mathrm{CEB}$ and actively participate in their technical committee structure.

The CEB recognizes that the U.S. is a vitally important potential technical contributor and is most anxious to include us in this cooperative activity. The major obstacle which must be faced is that within the U.S., the American Concrete Institute (ACI) in itself has become a center of international cooperation. Over three thousand of the 16 thousand members of ACI are from outside of the U.S. The technical standards produced by ACI are currently widely used, not only in the U.S., but throughout most of Latin America and many other countries such as Australia, New Zealand, Canada and the Middle East. The role which CBT has chosen is to attempt to establish avenues that will lead to technical cooperation between these two spheres.

The original approach that was made by CEB was that the U.S. join CEB as a full member. Such an action would be detrimental to the image that ACI has in the international technical community. Edward Pfrang has suggested that for the time being, we should put aside the question of one organization recognizing the other and get on with technical cooperation, letting recognition follow at some later date. This now seems to be acceptable to both ACI and to CEB.

In September of 1977, Edward Pfrang attended the CEB meetings in Granada, Spain, to seek areas for mutual cooperation between ACI and CEB. There he found a surprising receptivity to the thought of closer work with U.S. institutions, and in particular, with ACI. A number of discussions of possible avenues for cooperation were discussed with the Administrative Council of CEB, which corresponds to ACI Board of Direction. The one which surfaced as being most attractive was a joint activity toward a mutually acceptable performance code for concrete structures. Based on this conclusion, a resolution was drafted and presented to the General Assembly of CEB where it received unanimous endorsement. 


\section{CIB}

The Conseil International du Batiment pour la Recherche l'Etude et la Documentation (CIB) was established in 1953 in response to recommendations made by the United Nations Economic Commission for Europe. CIB's major objective is to encourage and stimulate international cooperation in the gathering, refinement, and dissemination of building research information. These mutual exchanges facilitate the development and adoption of building standardization practice, which in turn provide for the effective sharing of building research data and interchangeability of products on the international level. Fifty countries are currently members of CIB and send delegates from building-oriented organizations to participate in various CIB activities.

Lawrence Galowin, chief of CBT's Building Service Section, attended the annual meeting of the CIB 662 Plumbing and Drainage working group at the Norwegian Building Research Institute in Os 1o, Norway in May 1977. The group reviewed a draft of the preliminary requirements for a minimum performance plumbing code as a technological contribution to less developed countries. The draft was returned to the authors for modification and resubmission to the October 1978 meeting for further consideration and expansion.

During the past year, David Didion, CBT's Chief of the Mechanical Systems Section, traveled abroad to attend a meeting of the Technical Sub-Group on Heat Pumps of the CIB W67, "Energy Conservation in the Built Environment." This was the first meeting on heat pumps and included 21 reports from 12 countries. In representing $\mathrm{CBT}$, he was the only American in attendance and therefore tried to present the state of the American heat pump industry as wel1. At present, America is the only country that manufactures unitary heat pumps for both heating and cooling.

Likewise, Robert R. Jones, CBT's Program Manager for Energy Conservation, attended the January 1977 meeting of CIB W67 in Brussels. Among other papers delivered at the meeting was an interesting one by Mr. Uyttenbroeck, of Belgium, who demonstrated, by means of a series of equations on the chalkboard, the need for studies on free heat. Free heat is evidenced by the fact that an unoccupied building will have an indoor temperature higher than the outdoor temperature. 


\section{DESBRO}

In September 1977, Richard N. Wright, the Director of CBT, attended the meeting of the Directors of English Speaking Building Research Organization (DESBRO), which meets once every three years.

This group activity affords the Directors opportunities to pick up techniques and technical information from the other Directors; this in turn increases the effectiveness of NBS as a building research laboratory. Moreover, the close personal relationships with the other Directors of English speaking building research organizations increase the effectiveness of communications when special needs arise and provide good opportunities for the development of cooperative or complementary programs .

Among the many discussions at this year's meeting were presentations on flexitime at the Australian Division of Building Research, energy performance policy in Canada, and a request from tropical nations to push for practical solutions to water heating needs, the only substantial factor related to building in their national energy consumption picture.

Educational efforts were also reviewed for effective translation of the new knowledge and practice to design professionals and tradesmen. There was agreement that these efforts must be effective for public benefits to be realized from building research.

A variety of activities is underway. South African staff supervise University theses, Ghana staff offers course work at the University, Indian staff provide extension courses across the country as well as teaching at the local university. T. L. Webb, of South Africa, offered the approach "Teaching the teachers." In a country as large as the U.S. even this may not offer enough leverage; perhaps we need to teach the teachers of teachers.

There was general concern that the repetition of defects in building show that knowledge is not effectively applied. Materials such as the Canadian "Building Research Digests" and the Australian "Notes on the Science of Building" appear effective. Still, the great size of the U.S. building community suggests that we need look for a method with higher leverage than direct mail to disseminate this type of information. 


\section{ISO}

The International Organization for Standardization (ISO) is comprised of the national standards bodies of some eighty countries. The work of ISO is aimed at world-wide agreement on international standards for the purpose of the expansion of trade, the improvement of quality, the increase of productivity, and the lowering of costs.

An International standard is the result of agreement between the member bodies of ISO. A first important step toward the International Standard takes the form of a draft proposal--a document circulated for comment within the technical committee. But the draft must pass through several stages before it can be accepted as an International standard. This procedure is designed to ensure that the final result is acceptable to as many countries as possible.

In December of 1976, Charles Mahaffey, of CBT's Office of Building Standards and Codes Services, participated in the second meeting of the Divisional Council of Technical Division 3 of ISO. The central theme of this meeting concerned the proposal for the establishment of an international building standards center. This proposal represents a studied response to the problems identified at the first meeting of the Divisional Council (June 1976). Those problems were centered in two areas: (1) the slowness of the development process (particularly in the preparation of draft standards), and (2) the difficulties in maintaining technical coherency among the standards produced by the scattered and relatively independent Technical Committees, Subcommittees and Working Groups (a situation that is expected to worsen as the number of such groups is increased).

Earlier, Charles Mahaffey had participated, as a technical advisor to the USA delegate, Milton Francis of HUD in an ad hoc meeting of experts in the field of performance-based building standards, which was held in Sofia, Bulgaria, in October 1976. This meeting was another step in a large international project operating under the auspices of the United Nation's Economic Commission for Europe (ECE). This project is aimed at developing and implementing a inethodology for harmonizing the technical content of building regulations utilizing a 
performance-based approach and involving standards developed by the International Organization for Standardization (ISO).

In March 1977, Charles Mahaffey participated in the second meeting of Subcomittee 3 of Iso Technical Committee (TC) 59. This is the ISO Committee charged with developing the methodology, terminology, and format to be used in the application of the performance concept to all future ISO building standards. Since this committee will establish the basis for the writing of all future performance-based building standards, it is judged to be the single most important standards committee in the world.

Likewise, Emil Simiu attended ISO meetings in Gothenburg (September 1976) and London (November 1976) for members of the "wind loads" technical committee. The meetings were devoted to presentations and discussions of draft code provisions on various aspects of wind loading. Draft code provisions and supporting papers were presented jointly by Mr. Bietry and Emil Simiu under the titles, "Mean Wind Profiles and Change of Terrain Roughness" and "Dynamic Along-Wind Response of Tall Buildings". 


\section{INTERNATIONAL ENERGY AGENCY}

In October 1976, Elmer R. Streed, a mechanical engineer in CBT's Thermal Engineering Section, participated in the second experts meeting of the International Energy Agency, Committee on Energy Research and Development, Working Party on Solar Energy, held in Wiehl, Germany. He also attended a meeting on advanced collector system tests in Freiberg, with visits to experimental solar heated houses at Aachen and Heidelberg.

The primary area of study is the performance of solar heating-cooling systems. Initial system modeling and simulation studies by four countries (Denmark, Germany, Japan, and U.S.A.) were reviewed and some difficulties in computer compatible tapes were resolved. One-year building load tapes (CBT townhouse) for Madison, Wisconsin, Santa Maria, California, and Denmark were distributed at the meeting by CBT. Additional tapes for German and Japanese weather will be run by CBT soon. The solar system performance of two selected systems will be calculated using a detailed and simplified computer program developed in each country. The results will be compared.

In the solar area, each country briefly described recent developments related to component development, with a majority of the work on collector research. A greater concern and effort to reduce collector costs rather than to great ly improve performance is indicated by the European countries. Most countries are striving for a collector cost of $\$ 100 / \mathrm{m}^{2}$ or less but have been unable to do so for heating applications. Sweden reported a mass-produced roof integrated collector for $\$ 50 / \mathrm{m}^{2}$ that is currently under evaluation.

A review of outdoor performance testing experience by each country indicated the great difficulty encountered in trying to obtain all data points prescribed in CBT's report, Method of Testing for Rating Solar Collectors Based on Thermal Performance. The lack of clear days and the variability in sky temperature, wind, and diffusion ratio all contributed to testing periods of one month or longer and uncertainties that made it impractical to rate the performance of collectors. Therefore, the use of solar simulators and/or indoor measurements of the 
loss coefficients were being investigated by most of the nine represented countries.

A detailed analysis and design of the Freiberg-Colorado State Project, a multi-family hot water heating system, was described. The proposed collector is a new evacuated-tube design by Phillips. The U.S. will use the evacuated fin-tube design developed by Corning. The Colorado State University system is scheduled to commence in early 1977 and the Freiberg system in about one year.

The Phillips experimental house in Aachen combines energy conservation, solar collectors, and long-term thermal storage. The system employs an evacuated tube collector with a liquid heat transfer fluid. The general conclusions from the past year of operating experience indicate that seasonal storage is not feasible because of excessive thermal losses. The collector design currently in use is economically impractical because it is not amenable to low-cost mass production. It is indicated that solar heating in central and northern Germany is not economically justified at this time and will require a thermally wel1-designed building to be practical. The use of a heat pump with a ground heat source and sink design and some thermal storage for off-peak power use appears more promising. 


\section{INTERNATIONAL SEMINAR ON HEAT TRANSFER IN BUILDINGS}

Joseph Chi, a mechanical engineer in CBT's Mechanical Systems Section, attended the 1977 International Seminar on Heat Transfer in Buildings at Dubrovnik, Yugoslavia for presentation of a paper on computer simulation of residential heating boilers.

The seminar was attended by about 180 persons and 81 papers were presented. Much interest was shown in the CBT work on heat pumps, boilers/furnaces, and Stirling engines. For example, many questions followed the presentation of papers on the boiler simulation and Stirling engine driven heat pump. In particular, Peter Warren of British Building Research Station and D.J. Nevrala of British Gas Corporation expressed interest in future cooperation with NBS in these works. 


\section{INTERNATIONAL TOTAL ENERGY CONGRESS: ITEC}

In October 1976, John D. Ryan, a CBT mechanical engineer, attended the ITEC meeting held in Copenhagen. One paper given at the conference merits particular attention relative to current CBT studies in totalenergy systems. The paper, "Aldershot P.D.A. -- Total Energy Power Station with District Heating", presented the operating experiences of a diesel total-energy system over a 10-year period. The engines used were four Mirrlees 12 -cylinder $2140-\mathrm{kW}$ units operating on heavy residual fuel. This lengthy paper provides details on all aspects of plant design, operation and control. Also included is substantial inforination on the district heating system to which the plant is connected. In private discussions with the author, significant further points were brought to light which were not dealt with in the paper.

During the conference, a special technical tour was arranged for a small group by the Copenhagen district heating department. This visit included the Amager refuse incinerator, which supplies heat to the district heating system. A very modern plant (1970) serving a population of 550,000, this typifies European refuse incineration practice. Important Eeatures of this plant are: no auxiliary fuel firing, no separation of garbage except by separate collection of bulky items, a dry furnace, very clean and odor free, electrostatic precipitators, $100 \mathrm{~T} / \mathrm{day}$ maximum capacity. Heat transfer tube life has been very short due to low return water temperature $\left(70^{\circ} \mathrm{C}\right)$ from the district-heating system. An intermediate loop design is now thought to be a better approach. A brochure on this plant includes some cost data.

This tour also included district-heating piping installation activities. The Copenhagen system consists of both steam and hot water distribution, because the system is quite old (1925). At present three-fourths of the connected load is steam and one-fourth hot water. The maximum distance of heat transmission (plant to farthest customer) is $8.7 \mathrm{~km}$. 
The post-conference study tour centered on a trip to the district heating plant for the Danish town of Odense on the island of Funen. The total electrical capacity was $656 \mathrm{WW}$ and both coal and oil fuels are used. This plant is interesting in that the most recent unit (September, 1974) is of a type beginning to be very common in Scandanavia. It produces $230 \mathrm{MW}$ and $325 \mathrm{MW}$ in normal operation but can switch to $285 \mathrm{MW}$ in straight condensing duty.

The district heating system serves 23,500 households (1974) with about $90 \%$ saturation in the area covered by district heat. (Electrically, the plant is connected to the grid of Funen and the mainland of Jutland). The system $(735 \mathrm{~km})$ also includes 10 satellite, remotely-operated oilfired boiler stations for peak loads and security. As with all modern European installations, the system is based on pressurized hot water, in this case at $85^{\circ} \mathrm{C}$ normal, $105^{\circ} \mathrm{C}$ maximum delivery temperature.

In a presentation to members of the Study Tour, it became obvious that communications would be easier if certain standardized approaches to reporting data from these types of plants were available. Data presented on demand factor, capacity factor, load factor, efficiencies, and losses all caused some confusion. The CCMS-MIUS "standard methodology" could have served a useful purpose. (See the following section of this report, on the NATO project).

Opportunities for CBT-related research in the district heating areas are significant. Metering of hot water and steam energy is a key area. Metering problems are now causing concern in the U.S. (steam) and in Europe (hot water). This may be considered a barrier to implementation in the U.S.

Piping systems are a major cost item of any such system. Efforts to reduce costs so that lower-density areas can be supplied has promulgated many new piping systems and material applications. Test methods for these innovative piping systems are under development in Europe. Test methods and performance/reliability data need to be developed for: these systems to be widely used in the U.S. 


\section{NORTH ATLANTIC TREATY ORGANIZATION CCMS-MIUS PROJECT}

The Committee on the Challenges of Modern Society (CCMS) was established in 1969 by the North Atlantic Treaty Organization (NATO) to promote the effective and continuing exchange of information, technology, and experience to create a better environment. In May 1974 the pilot study, "Rational Use of Energy," and its sub-project, "Modular Integrated Utility and Total Energy Systems," known as the CCMS-MIUS Project, were established.

Both the pilot study and the sub-project are led by the U.S. The CCMSMIUS Project was established because of international concern over the need to provide more utility services to communities while improving energy utilization ard the environment. The U.S. Department of State assigned the lead role responsibility of the CCMS-MIUS Project to the U.S. Department of Housing and Urban Development (HUD) which also sponsors the HUD-MIUS Program.

The Center for Building Technology is supporting HUD by representing the U.S. in the CCMS-MIUS Project. This includes committee participation, developing the technical reporting system, administrative and technical leadership, and supplying technical data from the HUD-MIUS Program demonstration.

In October of 1976, a CBT staff member working on the MIUS project, Morris H. Nimmo, participated in the Candian Building Congress (CBC) at Toronto. He also participated in a seminar in Toronto given by the Swedish Trade Commissioner on District Heating Systems in Scandinavia.

The three-day $C B C$ was attended by approximately 600 persons mostly from the Canadian government, industry, and consulting firms. Paul Achenbach of CBT also attended and delivered a paper on "Development of PerformanceBased Energy Conservation Standards for Building." 
The Congress dealt with three major themes:

(1) Present and future sources of energy for supplying the heat and power needs of buildings.

(2) Energy conservation through improved building design and operation.

(3) Design of communities so that by-product heat from industrial operations can be utilized.

Papers were given on the following topics: energy conservation through improved building design and operation, use of by-product heat, criteria and standards for energy conservation, and design of communities. The session on utilization of by-product heat was of particular interest to integrated utilities systems. Six other papers were delivered on by-product heat in buildings and district heating.

The Swedish Trade Commissioner's seminar featured papers on large-scale power generation, heat production, and heat recovery from power plants. The papers delivered were:

- "District Heating--A Step by Step Approach" by Erik Wahlman, Engineering Director, H. Theorells Eng. Co (SWECO-group).

- "Combined Production of Heat and Power" by Bertil Koehler, Manager of Energy Technology Dept., AB Energikonsult.

- "Large Systems--Nuclear Stations, New Developments," Peter Margen, Chief Engineer, $A B$ Atomenergic.

- "Solid Waste--Source of Heat" by Grels Berg, M.Sc., AB Energikonsult.

- "Economics, Financing and Institutional Framework" Ake Karlberg, Chief Engineer and Vice-President, Sodertorns District Heating Company.

These papers are of direct interest to the HUD-MIUS Program and Integrated Utilities systems. The seminar also included presentations by manufacturers of hardware for district heating systems and distribution networks. In general, it is apparent that countries around the world are finding the MIUS concept very attractive.

Canada is definitely moving in the direction of energy conservation and the development of future supplies. Canada is self-sufficient in energy at this time, and is already beginning to curtail exportation of oil, and cut back on power and heating in government buildings. They appear to have a better opportunity to solve their energy problem than the U.S. since they have not reached a critical stage where they rely on imports. Canada thus has good potential for district heating, and heat recovery from power generation. 
The Swedish Trade Commissioner's Seminar was very convincing about the advantages of district heating, power generation and heating combined, and heat recovery from solid waste incineration and nuclear power plants. Back pressure production plants will be promoted in Sweden as their overall efficiency is about $85 \%$, as opposed to condensing power based on oil or other fossil fuels, where efficiency is below $40 \%$. Sweden is moving toward the supply of all heat by district heating and combined production of heat and power. Space heating by home furnaces will be the exception rather than the rule. At present large portions of their towns are heated from district sytems. The U.S. should examine these types of sytems very closely.

In July 1977, the CCMS-MIUS held its fifth meeting near Turin, Italy, where forty-three experts in integrated utility systems from 12 countries worked to develop and publish an International Project Catalog and a standard methodology for measuring the performance of integrated utility systems. The Catalog identifies 200 integrated utility projects in the participating countries. The Catalog describes each project, its status, the approach, expected results, some technical data, and an indication of what data will be available. The standard methodology identifies those elements and measurements that are essential in assessing the system performance of an integrated utility system. 


\section{RILEM}

The Reunion Internationale des Laboratories de'Essais et de Recherches sur les Materiaux et les Constructions (RILEM) is an international nonprofit association governed by Swiss Law. Its aim is to constitute a medium of exchange and of communication of scientific experience, especially the experience acquired by the study of materials and building elements, by observation, by tests in the laboratory and in-situ, and by research. The 1975 RILEM membership list shows representatives from 70 countries with a total membership of 679 persons. Recently RILEM has become more active in international standards organizations, particularly the International Organization for Standardization (ISO) and has adopted the policy whereby each technical committee must summarize its recommendations as prospective standards and submit them through the Permanent Committee of RILEM to ISO for international standards.

James R. Wright, Acting Director of NBS's Institute for Applied Technology--of which CBT is a part--is beginning his third year of a four-year term as a member of the RILEM Bureau. The Bureau of RILEM corresponds to the Board of Directors of an organization such as the ASTM in the United States. Concurrently, he is beginning his third year of a five-year term as the RILEM Delegate for the United States, and in this capacity represents 24 US RILEM members.

At this year's RILEM Coordinating Group Meeting in April 1977, William C. Cullen, Assistant Chief of CBT's Structures, Materials and Safety Division, continued his work as a member of the group's five-man executive force (his term expires in 1980). The Coordinating Group is responsible for developing and promulgating guidelines, for the operation and technical activities of over 30 RILEM committees, and the coordination of these activities with other technical organizations, such as, CIB. The Coordinating Group meets in executive session once each year and then in joint session with RILEM's Advisory Committee. 
At last years' meetings, the annual reports of all RILEM technical committees, which were submitted to the Coordinating Group, were reviewed. Progress, as well as technical accomplishements, were noted and discussed. The reports also included the various symposia sponsored by the respective committees and the recommendations prepared by them. The accomplishments and output of the respective technical committees were reviewed in terms of the planned objectives. Based on the reports and the discussion of the reports during the meeting, a progress report to the Permanent Committee of RILEM was prepared. This report was presented to the Permanent Committee of RILEM at the annual meeting in Budapest, Hungary in September 1977.

Also, the third draft of a publication "Guidelines for Technical Committees of RILEM" was reviewed and edited. The document is now ready for publication and will be sent to technical committee members in the near future.

The Coordinating Group also identified a need for the various technical committees to coordinate their efforts with other technical committees of RILEM, as well as with related technical committees of CIB. The next meeting of the Coordinating Group is scheduled to be held in Luxembourg in April 1978.

William Cullen also chaired the Stockholm meeting of RILEM Technical Committee 27-EVS on the "Evaluation of External Vertical Surfaces of Buildings," in September 1976.

Likewise, in December of 1976, Thomas $W$. Reichard, a physicist in CBT's Structures section, went to Stockholm to participate in organizational meetings for a new RILEM technical committee ( 42 CEA) on "Properties of Set Concrete at Early Ages." The purpose of the committee is to collect and analyse existing knowledge, prepare a state-of-the-art report, identify needed research, and recommend methods of measuring and characterizing the properties of concrete at early ages. For the purpose of this committee "early age" is defined as being from the time of placing up to about 24 hours (as much as 48 hours for some atypical concretes). This definition is at variance with common U.S. usage where "early age" is thought of as being up to about 7 days (in some cases, in fact, it can be any age less than 28 days).

The second RILEM/ASTM/CIB Symposium on the Performance Concept was held in Helsinki, Finland, on August 26-September 1, 1977. The Conference was held at the University of Technology and the Technical Research Center of Finland, Otaniemi. The first RILEM/ASTM CIB Symposium was held in Philadelphia in 1972. That Symposium was entitled the Performance Concept in Buildings.

The current Symposium in Helsinki was entitled Evaluation of the Performance of External Vertical Surfaces of Buildings. James R. Wright, Acting Director of NBS's Institute of Applied Technology and William Cullen, Assistant Chief of $\mathrm{CBT}^{\prime}$ 's Structures, Material and Safety Division participate 
James R. Wright's role included (1) conference development and (2) conference participation. He was chairman of Session II, "Factors Affecting External Vertical Surfaces."

William Cullen's involvement included (1) chairman of RILEM Technical Committee 27-EVS; (2) member of the Program Committee, and (3) active participant. As chairman of Technical Committee 27-EVS and member of the Program Committee, he was actively engaged in organizing the conference, planning the technical sessions, reviewing and selecting papers, as well as in selecting session chairmen and general reporters.

The annual meeting of the Permanent Committee of RILEM took place in Budapest, Hungary, at the Budapest Hilton Hotel. The meeting was attended by 46 delegates and representatives from 26 different countries. William Cullen attended this meeting. 
CBT makes its facilities available to qualified professionals to pursue individual scientific or technical building projects. Last year, the following guest workers had assignments at CBT:

February 15, $1975-$

November 26, 1976
March 1, 1977 -

June 30,1977

July 5, 1977 -

December 1977
Ricardo Guerra Florez, Architect Instituto de Pesquisas Tecnologicas Sao Paulo, Brazil

Assigned: Office of Housing and Building Technology

Subject: IPT/CBT Cooperative Program (Performance Criteria for Building Systems and Subsystems)

J. E. Raduan

Instituto de Pesquisas Tecnologicas Sao Paulo, Brazil

Assigned: Office of Housing and Building Technology

Subject: IPT/CBT Cooperative Program (Electrical Wiring System Performance)

M. H. F. Montenegro

Instituto de Pesquisas Tecnologicas Sao Paulo, Brazil

Assigned: Office of Housing and Building Technology

Subject: IPT/CBT Cooperative Program (Plumbing System Performance)

Juan Fregolente

Instituto de Pesquisas Tecnologicas Sao Paulo, Brazil

Assigned: Materials and Composites Section

Subject: IPT/CBT Cooperative Program (Methods for Evaluating Performance and Durability of Building Materials 
Listed below are the addresses of international organizations that CBT worked with last year. But in addition to the cooperative research programs previously described, CBT maintains close ties with many other building organizations by exchanging building information and making professional visits to research laboratories and organizations worldwide. These organizations are also listed below.

Australian Commonealth Scientific and Industrial

Research Organization, Division of Building Research

P.o. Box 56, Highett, Vic. 3190

Melbourne, AUSTRALIA

Australian Department of Housing Construction

P.O. Box 690, Canberra City, A.C.T. 2601

AUSTRALIA

Building and Road Research Institute

Council for Scientific and Industrial Research

University P.O. Box 40

Kumasi, GHANA

Building Research Institute

Technical University in Prague

Solinova 7, Praha 6-Dejuice

Prague, CZECHOSLOVAKIA

Building Research Institute

28-8 Hyankunin-Cho 3-Chome

Shinjuku-ku

Tokyo 160, JAPAN

Central Building Research Institute (CSIR)

Roorkee (U.P), INDIA

Centre Scientifque et Technique de la Construction

International Relations, Rue de Lombard, 41

Brussels, BELGIUM

Centro de Investigaciones de Ingeneria

Ciudad Universitaria Zona 非12

Guatemala City, GuATEMALA C.A.

Cement Industry Research Institute (VDZ)

4 Dusseldorf Nord

Tannenstrasse 2, GERMAN FEDERAL REPUBLIC

Danish Building Research Institute

Postbox 119, DK 2970

Horsholm, DENMARK 
Division of Building Research

National Research Council

Ot tawa, CANADA KIA OR6

Department of Mechanics

Technion - Israel Institute of Technology

Haifa, ISRAEL

Division of Building Materials

The Lund Institute of Technology

Box 725

22007 Lund 7, SWEDEN

Institut National des Science Appliques Direction 209, 20, Avenue A. Einstein 69621 Villeurbanne Cedex, FRANCE

Institutul de Cercetari in Constructii

Sos, Pantelimon nr. 266- Sectorul 3

Bucuresti, ROMANIA

Institute of Concrete and Reinforced Concrete of the USSR

Gosstroy, 2nd Institutskaya U1.6

109389 Moscow, USSR

Jamaica Bureau of Standards

P.0. Box 113

Kingston, JAMAICA

Laboratory of Building Technology

State Institute of Technical Research

02150 Otaniemi, FINLAND

Ministry of Housing and Urban Development

P.0. Box 15-1114

Tehran, IRAN

National Building Research Institute

Council for Scientific and Industrial Research

P.O. Box 395

Pretoria, SOUTH AFRICA

Nationa1 Industria1 Standards Research Institute Ministry of Commerce and Industry

199, Dong Sung-Dong

Chong Ro-Ku, Seoul, KOREA

Paint Research As sociation

Waldegrave Road

Teddington

Middlesex TW1 1 8Ln, ENGLAND 
Philippine Bureau of Standards

Quezon City, PHILIPPINES

The Royal Institute of British Architects

66 Portland Place

London, WIN 4AD, ENGLAND

School of Architecture

The Royal Institute of Technology (KTH)

S-100 44 Stockholm 70, Stockholm, SWEDEN 
CBT also provides an opportunity for foreign visitors to obtain information pertaining to research conducted at the Bureau and other U.S. building research organizations. Arrangements are made annually to visit U.S. laboratory facilities and technical staff specializing in particular building areas. Thus, building professionals of foreign countries and CBT staff have an opportunity to exchange information and ideas on an informal basis.

July 9, 1976

July 12, 1976

Ju 1y 15, 1976

July 22, 1976

July 22, 1976
Professor Igbal Shah

University of Peshawar, Pakistan

Subject: Mechanical Engineering and Solar Energy

Mr. \& Mrs. Ch. Krenge 1

Building Research Station, Israel Subject: Administrative Aspects of Building Technology

Policarpo Vitti

Institute of Food Technology, Brazil Subject: Project Planning and Control

Japanese Group

Subject: Solar Energy

Professor Dr. Tsuneyoshi Uyemura Dep. of Precision Machinery Eng., Faculty of Eng., Univ. of Tokyo

Mrs. Miyoko Uyemura

Asso. Prof. Dr. Shigeo Ohzono

Dep. of Precision Machinery Eng.,

Faculty of Eng., Univ. of Tokyo

Instructor Dr. Yoshitaka Yamamoto Dep. of Precision Machingery Eng., Faculty of Eng., Univ. of Tokyo

Instructor Mr. Takao Tsuno

Eng. Research Institute

Faculty of Eng., Univ. of Tokyo

Mr. Zacharia George

National Research Lab.

Madras, India

Subject: Housing, Structural Engineering, and Pre-stressed Concrete 
lugust 9, 1976

lugust 24, 1976

August 27, 1976

September 2, 1976

September 7-14, 1976

September 16, 1976

October 21, 1976

November 4, 1976

November $8-9,1976$
Professor Baruch Givoni

Building Research Station, Israel

Subject: Energy and Solar Heating and Cooling

Australian Scientists \& Engineers (12 individuals) The Combustion Institute

Melbourne, Australia

Subject: Solar Energy

Professor T.J. Olivier

University of the Witwatersrand

Johannesburg, South Africa

Subject: Housing, Systems Buildings

and Evaluation

Dr. Ian McLeod

Paisley College of Technology, Scotland

Subject: Structural Engineering and Housing Technology

Dr. Philippe Eurin

Chief, Materials Section CSTB

Grenoble, France

Subject: Materials

Ephraim Winter, Head

Sanitary Appliances Section, Hydraulics Laboratory

Standards Institute of Israel

Subject: Water Supply, Sewage Projects, and Plumbing Research

CIB Programme Committee ( 8 individuals)

Liesje ten Hauten, Coordinator BRAB

National Research Council

Washington, D.C.

Subject: Building Technology and Research

Dr. Hormoz Famili

Building \& Housing Research Center

Ministry of Housing and Urban Development

Tehran, Iran

Subject: Materials, Structures, and

CBT Research

Dr. Erwin Petersen

The Danish Illuminating Engineering Laboratory Lyngby, Denmark

Subject: Sensory Environment, Thermal, and Solar Research 
November 8, 1976

November 12, 1976

November 17-19, 1976

November 22, 1976

December 6-7, 1976

December 13, 1976

January 13, 1977

January 17, 1977
Dr. Ake Skarendah 1

Mr. Stig Ostfjord

Swedish Cement and Concrete Research

Institute

Stockholm, Sweden

Subject: Cement and Concrete Research

Mr. Kyu-Hyun Lee

Industrial Advancement Administration

Ministry of Commerce \& Industry

Seoul, Korea

Subject: Energy Conservation, Solar Energy, and Control Systems

E11io P. Souzi, M.E.

Head, Maintenance and Fuel Efficiency Dept.

Israel Institute of Productivity

Hakiryah, Israel

Subject: Energy Conservation and Fuel

Efficiency

Members of the Metallurgy Section ( 6 individuals)

Institute of Nuclear Energy Research

Republic of China

Subject: Fire Research, Standards and Codes, Environmental Engineering Lab

John Nicholas, Deputy Chief

Division of Building Research

CSIRO, Australia

Subject: Town Planning, Urban and Regional

Development, Architectural Physics, Fire Research, Consumer Activities, Building Technology

Professor M. Farzan

Iranian Oil Co., Iran

Subject: Air Conditioning \& Electronic Instrumentation

Mr. Kyu-Hyun Lee

Industrial Advancement Administration

Ministry of Commerce \& Industry

Seoul, Korea

Subject: Energy Conservation in Industry

Jean Pierre Plumensi

Scientific Attache, French Embassy

Washington, D.C.

Subject: Fuel and Energy Conservation, Trends in Heating and Electricity 
January 18,1977

February 9, 1977

February 14, 1977

February 18,1977

February 22, 1977

March 29, 1977

April 13, 1977

May 5, 1977

May $9-10,1977$
Soviet Delegation

USSR State Commission on Construction,

State Projecting Institute and

Central Research Institute

Subject: Discussion on US/USSR Housing

Agreement, Building Design and

Construction

Dr. A. Shenhar, Director

National Physical Lab of Israel

Jerusalem, Israel

Subject: Energy Conservation in Industry

Technology $\operatorname{Transfer}$ Institute of Japan

(16 individuals)

Tokyo, Japan

Subject: Energy Conservation in Buildings

Air Conditioning \& Heating Engineers Group

Sanyo Company Japan

Subject: Heating \& Air Conditioning Systems

Engineering Study Team

Japan Research Corporation

Tokyo, Japan

Subject: HVAC Systems, Solar Energy

Professor J. Bougard

Technical University Mons, Belgium

Subject: Solar Energy

Darrel1 Eagles

Public Works

Ottawa, Canada

Subject: Information Technology Transfer

Ehsam Katmeh

Geological Survey \& Mineral Resources, Ministry of Petroleum \& Raw Material

Damascus, Syria

Subject: Properties of Sand, Clay, and Gypsum, building materials

John Morris, Head

Organic Materials Division, CSIR

Praetoria, South Africa

Subject: Properties and Behavior of Plastics in Fire 
May 17,1977

May 19, 1977

June 2, 1977

June 8, 1977

June 14, 1977

June 17,1977

July 11,1977

July 12, 1977
Jan Lindgren

Managing Director

Swedish Building Center

Stockholm, Sweden

Subject: Standards, Technical Research

Management, Information Dissemination

Mr. R. Rossi, Director

CSTB, France

Paris, France

Subject: Overview of Building Research Technology

Ramachandra Murthy, Scientist

Structural Engineering Research Centre

Madras, India

Subject: Prefab Housing Systems and Prestressed

Concrete

Nahum Granot, Director General

Building Centre for Israel

Tel Aviv, Israel

Subject: Solar Energy and Energy Conservation

Dr. Andrew Short, President

Comite European International du Beton

c/o Permanent Secretariat

Paris, France

Subject: Codes and Practices relating to Concrete

Research

Grethe Jensen, Deputy Director

Henry Gunst

Danish Factory Inspection Service

Stockholm, Sweden

Subject: Nondestructive Testing, Laboratory

Evaluation and Certification Programs

Delegation - People's Republic of China

China

Subject: General Building Technology

Philip G. Ruefel

Saskatschewan Minerals Ltd.

Canada

Subject: Solar Energy - Use of Sodium Sulphate in Solar Systems 
July 13, 1977

July 15, 1977

August 3, 1977

August 8, 1977

August 24, 1977

September 7, 1977

September 8, 1977

September 22, 1977

September 26, 1977

September 28, 1977
Drs. T. Lefeude, Director

F. Berry, Deputy Director

D. Hampton

Department of Public Works

Ottawa, Canada

Subject: Solar Energy

Paul Fazio, Ph.D., Eng.

Centre for Building Studies

Montrea1, Quebec

Subject: General CBT Research

Ehsan Katmeh, Deputy Director

The General Establishment for Geology \&

Mineral Resources

Damascus, Syria

Subject: Research Activities of the Structures, Materials, \& Safety Division

Mr. Lagaya

Manager, Information Research Division

Industrial Technology Association

J apan

Subject: Solar Energy

A. Rudnick, Director of Research

St andards Institution of Israel

Tel Aviv, Israel

Subject: Research \& Testing of Solar Collector

Popov Society USSR

USSR

Subject: Computers

Dr. Bryan Callaghan

Senior Chief Research officer

NBRI of the CSIR

South Africa

Subject: Corrosion of Metals and Performance of Metallic \& Organic Coatings

Messrs. Douillet and Brouard

Compagnie Generale d'Electricite

France

Subject: Solar Energy

Dr. Kodiyat

Director of Planning

Indonesia

Subject: General Technology

Dr. A. J. Bland

Corporate Research \& Development Department

London, England

Subject: New Technology 



\begin{tabular}{|c|c|c|c|}
\hline $\begin{array}{l}\text { U.S. DEPT. OF COMM. } \\
\text { BIBLIOGRAPHIC DATA } \\
\text { SHEET }\end{array}$ & $\begin{array}{l}\text { 1. PUBLICATION OK RLPORT NO. } \\
\text { NBSIR 77-1411 }\end{array}$ & $\begin{array}{l}\text { 2. Gov't Accession } \\
\text { No. }\end{array}$ & 3. Recipient"s Accession No. \\
\hline \multirow{2}{*}{\multicolumn{3}{|c|}{$\begin{array}{l}\text { 4. TITI.E AND SUBTITI.: } \\
\text { International Research } \\
\text { The FY } 1977 \text { Survey of } \mathrm{CBT}^{\prime} \text { 's International Programs }\end{array}$}} & $\begin{array}{l}\text { 5. Publication Datc } \\
\text { March } 1978\end{array}$ \\
\hline & & & 6. Performing Organization Code \\
\hline \multirow{2}{*}{\multicolumn{3}{|c|}{$\begin{array}{l}\text { 7. AUTIIOR(S) } \\
\text { Michael Olmert, Editor (CBT Conta } \\
\text { 9. PERIORMING ORGANIZATION NAME AND ADDRESS } \\
\text { NATIONAL BUREAU OF STANDARDS } \\
\text { DEPARTMENT OF COMMERCE } \\
\text { WASHINGTON, D.C. } 20234\end{array}$}} & 8. Performing Organ. Report No. \\
\hline & & & 10. Project/Task/Work Unit No. \\
\hline \multirow{2}{*}{\multicolumn{3}{|c|}{$\begin{array}{l}\text { 12. Sponsoring Organization Name and Complete Address (Street, City, State, ZIP) } \\
\text { National Bureau of Standards } \\
\text { Department of Commerce } \\
\text { Washington, D.C. } 20234\end{array}$}} & $\begin{array}{l}\text { 13. Type of Report \& Period } \\
\text { Covered }\end{array}$ \\
\hline & & & 14. Sponsoring Agency Code \\
\hline
\end{tabular}

15. SUPPI.EMENTARY NOTES

16. ABSTRACT (A 200-word or less factual summary of most significant information. If document includes a significant bibliography or literature survey, mention it here.)

This report presents the international research activities of the Center for Building Technology during the transition quarter and Fiscal Year 1977. In general, the objectives of this work were to spread the results of building research worldwide in hopes of creating a better built environment. Last year CBT continued working closely with less-developed countries to improve their building practices. The Center also continued cooperative research efforts with a number of countries that have acknowledged expertise in particular areas of building research, such as England, Israel, and France, to name but a few. On such projects, the Center pursued common research goals alongside the building researchers from other nations on studies of critical importance to all nations, such as energy and natural resources conservation.

17. KEY WORDS (six to twelve entries; alphabetical order; capitalize only the first letter of the first key word unless a proper name; separated by semicolons) Building practices; building research; codes and standards; housing; international cooperation; technology transfer.

X Unlimited

For Official Distribution. Do Not Release to NTIS

[ Order From Sup. of Doc., U.S. Government Printing Office Washington, D.C. 20402, SD Cat. No.C13

X Order From National Technical Information Service (NTIS) Springfield, Virginia 22151

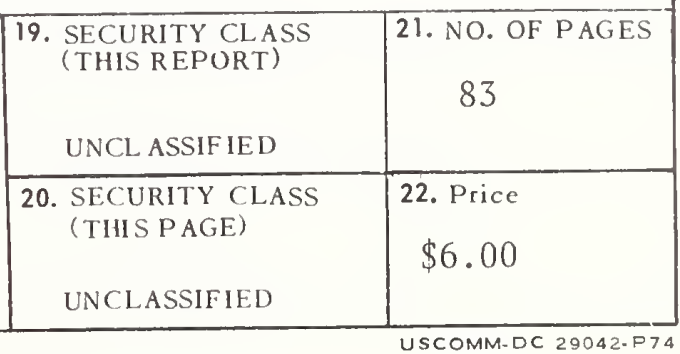


